\title{
"You know very well you're not real": Victorian children's fantasy literature and the problem of writing the Child
}

by

Beatrice Turner

\author{
A thesis \\ submitted to Victoria University of Wellington \\ in fulfilment of the \\ requirements for the degree of \\ Master of Arts \\ in English Literature
}

Victoria University of Wellington

2009 


\section{CONTENTS}

Acknowledgements................................................... ii

Abstract.................................................................... iv

Introduction.............................................................. 1

Chapter One:

Who is reading? Children's literature criticism and the implied reader.

Chapter Two:

The Romantic Child reconsidered.

Chapter Three:

Alice and Curdie: the child in language.

Chapter Four:

Tom and Diamond: the child and death.

Chapter Five:

Griselda, Jeanne and Hugh reach the limits of fantasy: the return journey.... .94

Conclusion:

"I am real!".

List of Works Cited. 


\section{ACKNOWLEDGEMENTS}

The completion of this thesis would not have been possible without the support and encouragement of more people than I have room to thank here, so I would like to extend an open expression of gratitude to friends, flatmates, family and colleagues, all of whom have provided cups of coffee, intellectual sounding boards and shoulders to cry on at some stage.

First and foremost, enormous thanks are due to my wonderful supervisors Harry Ricketts and Anna Jackson for their guidance, patience and support, particularly in helping me to navigate foreign critical waters.

I would like to acknowledge the Friends of the Dorothy Neal White Collection for their financial assistance, and Lynne Jackett, Research Librarian of what is a fantastic and under-used children's literature collection, for her enthusiasm and help.

Thanks are also due to Professor Karin Lesnik-Oberstein and Dr. Neil Cocks of the Centre for International Research in Childhood Literature at the University of Reading. Both went far beyond the call of duty when I visited CIRCL on a research scholarship, providing me with invaluable advice and feedback. I am also grateful to Education New Zealand for funding the award.

I owe a special thank you to Lillian and Derek for passing down their books, to Phoebe for her common sense, and to a generation of Fry women for their strength.

Finally, I want to thank Nick for being who he is, and Jane for conversations in London which I will always treasure.

The last thanks of all are for Margot and Ian, who make everything possible. 


\section{ABSTRACT}

This thesis examines eight "Golden Age" children's fantasy narratives and uncovers their engagement with the "impossibility" of writing the child.

Only recently has children's literature criticism recognised that the child in the text and the implied child reader cannot stand in for the "real" child reader. This is an issue which other literary criticism has been at pains to acknowledge, but which children's literature critics have neglected. I have based my reading on critics such as Karín Lesnik-Oberstein, Jacqueline Rose and Perry Nodelman, all of whom are concerned to expose the term "child" as an adult cultural construction, one which becomes problematic when it is made to stand in for real children.

I read the child in the text as an entity which contains and is tainted by the trace of the adult who writes it; it is therefore impossible for a pure, innocent child to exist in language, the province of the adult. Using Derrida's conception of the trace and his famous statement that "there is nothing outside of the text," I demonstrate that the idea of the innocent child, which was central to Rousseau's Émile and the Romantic Child which is supposed to have been authored by Wordsworth and inherited wholesale by his Victorian audience, is possible only as a theory beyond language.

The Victorian texts I read, which include Lewis Carroll's Alice texts, George MacDonald's At the Back of the North Wind and the Princess texts, Kingsley's The Water Babies and Mrs. Molesworth's The Cuckoo Clock and The Tapestry Room, all explore different ways in which the child might be successfully articulated: in language, in death, and through the return journey into fantasy. While all the texts attempt to reach the child, all ultimately foreground the failure of this enterprise. When a language is created which is child-authored, it fails as communication and meaning breaks down; when the adult ceases to write the narrative, the child within it ceases to exist. 
Introduction 
We know nothing of childhood: and with our mistaken notions the further we advance the further we go astray.

- Rousseau, Emile

There is no child behind the category 'children's fiction', other than the one which the category itself sets in place, the one which it needs to believe is there for its own purposes.

- Jacqueline Rose, The Case of Peter Pan

Rousseau and Rose, two authors separated by two centuries, highlight the central problem of trying to say anything about children's literature: the inability of the adult to know or speak for the child. Criticism may have only recently identified that this is a contestable issue, but texts written for children have always engaged with this problem. Thacker and Webb formulate this tension as the "idealised relationship between adult author and child reader, formed out of the Romantic aesthetic, which serves as a model for subsequent writing for children in English. All children's literature, since its inception, engages in some way with this relationship, whether as a celebration of it, or in terms of its impossibility" (Thacker \& Webb 13). It is this idealised address which raises the issues which are central to children's literature: who is the "child" who is addressed? How can any text assume knowledge of what constitutes either the child within the text, or the presumed child reader?

Rousseau, of course, used Émile to argue that the child could, in fact, be known. His "natural child" proposed that children were ideal creatures which were without 
reason or other signifiers of adulthood, and that this state was something which should be preserved and cherished for as long as possible. He argued against Locke's program of education through reason, believing that to cram children with rotelearned knowledge and expect them to function mentally as little adults would create "infant prodigies" but not fully realized adults (76). Rousseau famously stated that "Reading is the curse of childhood": Émile, aged twelve, "will hardly know what a book is" (81). For Rousseau, reading was not suitable for a child's mind since the written word is a representation of the spoken word, and therefore degraded. "As a general rule," Rousseau stated, "never substitute the symbol for the thing signified" (133). The child should be occupied, according to Rousseau, only with what was original, natural, pre-writing and pre-adult, since it was these qualities which made up the child itself.

Derrida engaged with Émile in order to demonstrate that nothing precedes writing; that any concept we have of something prior to writing is an illusion since it is only through writing that we understand that which we would privilege as prior: ...there never has been anything but writing; there never have been anything but supplements, substitutive significations which could only come forth in a chain of differential references, the "real" supervening, and being added only while taking on meaning from a trace and from an invocation of the supplement, etc. And thus to infinity, for we have read, in the text, that the absolute present, Nature, that which words like 'real mother' name, have always already escaped, have never existed; that what opens meaning and language is writing as the disappearance of natural presence ( $O f$ 
Grammatology 159).

Derrida's deconstruction of Rousseau's use of the "supplement" exposes the flaw in his construction of Nature as something prior to, and better than, culture and reason. I have drawn Derrida into my discussion since his well-known critique of Rousseau has serious implications for the Romantic model of childhood, and indeed for my reading as a whole. Rousseau aligns the child with Nature, as something prior to adulthood and reason, and crucially as something originally innocent and good. “According to Rousseau," Derrida writes, "the negativity of evil will always have the form of supplementarity. Evil is exterior to nature, to what is by nature good and innocent" (Of Grammatology 145). In exposing this lack of priority, of a point of origin that precedes writing, by extension Derrida claims that nothing precedes culture, reason and adulthood, at least in any meaningful way to which we, as adults, have access. The argument that there is no "child" before the adult, that there is no point of origin to which we may return in order to seek this pre-experienced figure, will be crucial to my reading of eight 'Golden Age' texts.

According to what might be called the "primer to pleasure" school of children's literature criticism, the "Golden Age" was a period in the second half of the nineteenth century, in Victorian England, when, to quote Mary Jackson, there “magically burst forth into view" a new wave of children's literature which differed markedly from previous children's fiction in its use of fantasy, the surreal, the magical and the subversive $(253)^{1}$. This is a reading of Victorian children's literature which has wide currency. The "classic" texts of the age, Lewis Carroll's Alice books,

\footnotetext{
${ }^{1}$ Mary Thwaite's 1963 text from which this school of thought takes its name (From primer to pleasure in reading: an introduction to the history of children's books in England: from the invention of printing to 1900 ), Geoffrey Summerfield's Fantasy and Reason and David Sandner's The Fantastic Sublime are examples of this branch of criticism.
} 
George MacDonald's fantasies, The Water Babies and Edward Lear's nonsense rhymes, among others, are situated as responding to the Romantics, and as opposed to the prescriptive, educative literature which preceded Romanticism and which was informed by the rational Enlightenment thinking of Locke in particular.

These texts are held up as "entertaining and subversive" and as constituted of “narrative strategies that invite a dialogic 'sharing' of the storytelling process between author and reader, rather than a controlling, authoritative and colonizing relationship" (Thacker \& Webb 41, 44). Above all, it is claimed, they respond to the Romantic, Rousseauean child and posit an "implied reader who embodies the potential of the Romantic child" with its associated qualities of innocence, purity, joy and innate one-ness with the world (Thacker \& Webb 43). The Romantic child is understood as a redeeming figure who effected a move from the adult as teacher to adult as pupil, from "stern moralizing to the undisciplined child to patient listening to the wise instruction of the simple and imaginative child" (Sandner 8). Sandner claims further that in the moral tale, the adults had instructed the children in ethics and right behaviour; in nineteenth-century children's fantasy, now the corrupted adults must follow the children to heaven - only childhood, through the purity of innocence and the force of imagination, could redeem fallen humanity (11).

What I intend to offer is an alternate response to the Golden Age texts, one which derives from a reading of the Romantic Child as a radically different figure to the child who came "trailing clouds of glory" (Wordsworth "Immortality Ode" 64). In 
Romantic texts such as Wordsworth's “We are Seven," Blake's Songs of Innocence and Experience and Hartley Coleridge's addresses to children, their authors acknowledge the difficulty, if not the impossibility, of knowing the child and consequently making any claims for its innocence. Indeed, as Blake's Songs of Experience articulates, the only thing which can be known about the child is its social and economic status. His experienced children, states Judith Plotz, "live vulnerably and angrily in history" and, as I shall argue, their self-awareness makes them much less horrific figures than their innocent, ignorant counterparts $(100)^{2}$. Innocence, for Blake, is not something that may be presumed for the child, and is certainly not necessarily a desirable childhood characteristic. Wordsworth is famously held to have proposed the innocent, self-contained Romantic child, but as others have argued, there is a question as to how much that child is drawn out of Wordsworth by a nostalgic Victorian readership, and in turn how much the "Victorian Wordsworth" is posited by twentieth century critics. As I shall argue, this construction comes under threat from within his own poetry when he considers how that self-contained child is in fact a thing alien and unknowable to adults, and also from the designated living embodiment of the Romantic child, Hartley Coleridge, whose poetry exposes both the paucity of the idea and its inability to refer to any real child.

My aim is to revisit eight Golden Age texts: Charles Kingsley's The Water Babies (1863), Lewis Carroll's Alice's Adventures in Wonderland (1865) and Through the Looking-glass (1871), George MacDonald's At The Back of the North Wind (1870), The Princess and the Goblin (1871) and The Princess and Curdie (1882) and Mrs.

\footnotetext{
${ }^{2}$ See, for example, James Kincaid's Child-loving: the erotic child and Victorian culture
} 
Molesworth's The Cuckoo Clock (1877) and The Tapestry Room (1879). I have chosen these texts because, firstly, they offer a fairly representative sample of Golden Age literature. More importantly, however, they all share a common unease with writing about and for children, and all take up the problem, engaged with to varying degrees by Blake, Wordsworth and Hartley Coleridge, of positing a unified, knowable child. They ask questions about what "the child" is, and if it exists outside the text, or whether, as Tweedledum tells Alice, the idea of the child is merely an adult dream which will "go out - bang! - just like a candle!" when the narrative ends (Wonderland 125).

Derrida's assertion of the impossibility of "presence," when applied to the field of children's literature criticism, reveals (particularly with regard to the reading of late nineteenth century texts) the kind of "claims to presence," as Neil Cocks terms them, that the critic is in danger of making: “'Child' and 'nineteenth century' as pure concepts, 'Child's point of view' and 'nineteenth-century attitudes' as native visions accessible to all" (Writing, Death and Absence 47). The move away from what Cocks views as an implicit adherence to the "construct 'Child' ... as an anterior framework, an unquestioned structure" is something which children's literature criticism has only recently attempted, yet in the texts to be read, it is possible to discern precisely these constructs being questioned (47).

Thacker argues that in Victorian children's fantasy the worlds of dream, fantasy and nonsense appear to subvert the rational 
world in much Victorian children's fiction... a shared recognition of the possibilities for redemption through a childlike, feminised, and 'natural' apprehension of the world provide a challenge to the forces of money, power, science and urban existence (Introducing Children's Literature 48). This thesis will argue against her claim that “texts such as Kingsley's The Water Babies or Carroll's 'Alice' books... offer narrative relationships between author and reader that are at once subversive and poignant" (48). While these texts may attempt to free the child in the book, that figure remains defined and controlled by adult characters who pop up, like Humpty Dumpty in Through the Looking-glass, in places of the most surreal fantasy to act out scenes of adult dominance. These narratives ultimately render the interpellated child reader as powerless and controlled as the implied reader of the Tractarian children's literature which dominated the market prior to the latter half of the nineteenth century. While, as Sarah Thornton believes, the Victorian age may have considered the child as a Rousseauean innocent in a fallen world, "a pure point of origin" and "part of a fantasy that the child and the world are knowable in a direct and unmediated way," the children's literature it produced struggled to articulate such a child (130). Narratives such as The Cuckoo Clock and the Alice texts may have aimed at producing a child in the text who was both innocent and free to move within a fantasy setting, but their narratives exposed, in Molesworth's case through the "return journey" plot device and in Carroll's through the adult characters' control over language itself, the impossibility of ever escaping the power relationship between adult and child, and, in turn, of creating the wholly innocent and originary child. 
Carroll and MacDonald, in making a concerted effort to write a "free" child and to imagine a space for the child that was truly anarchic yet never threatening, discovered that the child is at once forever limited and forever tainted by writing. I will not argue that Victorian children's fantasy did not attempt the subversive, the fantastical or the true freedom of the child. However these goals were undermined by both the nature of writing and language, which MacDonald in particular strove to overcome, and by the power structures from which no writer for children can ever escape. I argue that MacDonald and Kingsley, in attempting to write the child after death, find that writing death results in much the same moves as writing the child: either language breaks down and meaning is lost, or death becomes tainted with life and fails as a "pure" representation.

Similarly, the possibility of writing an innocent child becomes impossible since it will always remain a product of the experienced adult who wrote it, and it is very much this paradox which I see these authors as grappling with. The fundamental issue which confronted these texts, I argue, was the issue which still problematises children's fiction and its criticism today: the conflict between the theoretical impossibility of writing the 'child' and the unavoidable fact that the child continues to be written. It is to this problem as it relates to contemporary criticism of children's fiction that I now turn. 


\section{Chapter One}

Who is reading? Children's literature criticism and the implied reader 
It can of course be shown that the problem of claiming to know the child and the child reader is a problem for all literary criticism, as we can never satisfactorily reveal either the intended reader or the plurality of actual readers, just as we can never convincingly do more that posit an implied author. However, this is a complication which other criticism has been at pains to acknowledge, while as Jacqueline Rose, Karín Lesnik-Oberstein, and others have noted, children's literature criticism has been slow to accept that a unified audience of 'real' children is as problematic a concept as a unified audience of any text. ${ }^{3}$

Chris Jenks and, more recently, Thacker \& Webb, suggest that "While all literature is based on a power relationship... children's literature is based on a relationship that is less equal than that between adult reader and adult author" (Thacker \& Webb 3). The idea of the 'child' carries with it a structure of power and dependency relationships in which the adult, the one not only responsible for writing the child's book, but also criticizing it, buying it, mediating the child's access to it, and, crucially, interpreting the child's response to it, is always dominant. The child is a silent and powerless half of a dichotomy in which the adult can understand "adult" through first positing "child" while the child has no such ability (Jenks 3). Adults, as regulators of the child's reading and of the idea of the "child" itself, are invested with an "urgency of belief, asserted as knowledge, which is intricately involved with the need within Western society to capture, define, control, release and protect the 'child"” (Lesnik-Oberstein, Children's Literature 8). However, recent writing on the subject of childhoods and children's literature recognizes that this one-sided power relationship obscures the fact that there is an irreducible gap between "child" or

\footnotetext{
${ }^{3}$ This has been argued in Karín Lesnik-Oberstein's Children's Literature: New Approaches and Children in Culture: Approaches to Childhood, Neil Cocks' article "Writing, Death and Absence in Tim by H. O. Sturgis," and Perry Nodelman's The Hidden Adult: Defining Children's Literature.
} 
"childhood" as concept and real children and childhoods. James, Jenks and Prout put the question this way: "is it ever possible (or desirable) to speak meaningfully about ‘childhood' as a unitary concept?” (125).

To formulate it another way, the binary relationship between the signs of "adult" and "child" is loaded with such an unequal distribution of power that unlike other unitary concepts, the child "has not escaped or deconstructed into the post-structuralist space of multiple and self-presentational identity sets" (Jenks 3). Thus until relatively recently, the critic of children's literature was happy to speak of the "child" reader, their response to a certain text or to certain themes and devices, with a didactic certainty which I would argue is impossible. Nicholas Tucker, for example, is comfortable with statements such as (regarding the picaresque novel) "Obviously, this story pattern has enormous attractions for children, as they too have to make this particular journey" (23). For Tucker this is not only a fact, it is obviously one, and one which is implied to be a fact as regards all children.

Jill May, writing on the need to understand children's literature through critical theory, loads her text with assertions such as "For many contemporary schoolchildren, pleasure comes on a screen. They view reading as part of school work" and "The preschool child best identifies with a character about his own age" and, extending the claims to students of children's literature, "those students who hope to teach take the course because it is required. Those who are not in education hope to take an enjoyable but easy literature class...one group hopes to learn relevant modes of teaching that most often meet with success, while the other wants time 'to read like a child"” (May Children's Literature 4, 6, 40). Both of these 
authors are making unsubstantiated claims to know not only how a child reads, but what that idea of "child" constitutes.

May's assertion about why university students take children's literature courses is particularly interesting because it highlights precisely the power structures at work in these claims. As a children's literature student who is neither a potential teacher, someone hoping for an "easy literature class" nor a nostalgic trip down memory lane, I identify a flaw: I do not recognise myself in that construction, and I consequently critique May for formulating a reductive and unproven argument, an avenue not available to any child who may similarly be misrepresented. May's eagerness to pin down what it is that a child is and wants leads her to cross a line into assuming what it is that certain adults (children's literature students) want, and only once across that line are those adults able to take up her argument. Her claims for the child may be equally reductive, but to counter that they are wrong, that they propose an incorrect idea of children, would be to again impose an alternative meaning on the child. Instead, the critic can only highlight that a claim to know what the child is has been made, and that this is something to be wary of.

And yet this is a trap which continues to catch even those critics who actively acknowledge the dangers of claiming to know the child. Roderick McGillis, an authority on the works of George MacDonald and an author whose goal has been to recuperate children's fiction for the kinds of "adult" literary criticism from which it has arguably been excluded in the past, warns that "Language does not simply state truths; it creates them. We forget this when we blithely assume that we know what is best for children, that we know what literature they should and should not read" (The 
Nimble Reader 19). Yet in an examination of MacDonald's "The Giant's Heart" he states that "Most children will appreciate a story in which a child...defeats an adult authority figure" and speaks of the child reader who "delight[s] in subversive violence" (For the Childlike 12-13). The idea of the implied child reader on whose behalf a text makes claims is a problematic one not least, it seems, because it is so difficult to banish entirely.

Criticism which treats the child as a transparent, knowable entity, argue critics such as Lesnik-Oberstein and McGillis, is bound up in a project, acknowledged or not, to define and identify the "good book"; to judge which literature is appropriate for the child and which is not. Knowing the child is an essential prerequisite to knowing what s/he wants to, and should, read. Maria Nikolajeva, introducing Aspects and Issues in the History of Children's Literature, notes that this is an issue within children's literature from which the critic can never escape:

Children's literature emerged on a larger scale because at some time in the seventeenth century society began to recognize that childhood was a special period in people's lives and that children had their own special needs...The view of childhood and the educational aspects of reading have been crucial for the evolution of children's literature. It has gone hand in hand with pedagogical views; literature as a means, and a very powerful one, for educating children. Therefore, children's literature has been studied with this view in mind - that is, the suitability of books for children's reading (ix). 
Nikolajeva does raise an issue with the pedagogical approach, pointing out that it leads to histories of children's literature which are "highly manipulated recommendation lists" and which merely reflect the subjective judgments of the adult author or editor, although she maintains that it is not possible to entirely discard this approach in favour of discussing children's literature solely as literature, because "we can never ignore the simple fact that most books for children were produced solely for educational purposes" (ix,x).

It is worth unpacking this position, as it encapsulates some of the most pressing problems facing the criticism of children's literature. Firstly, it would appear that there is a claim here to know authorial intention in an absolute way. It is a "simple fact" that most children's literature has an educative purpose, declared or not. This statement recalls Nicholas Tucker's “obviously”, discussed above. The language indicates that these are facts which are not only concrete but self-evident, and whether or not the reader agrees with these statements, they are problematic in their refusal to account for themselves. These "facts," the text claims, are so absolute that no evidence need be offered. Having posited subjectivity and difference in the children's literature critic, the text does not extend the same possibility to the children's literature author.

So while Nikolajeva identifies that there might be a plurality of subjective views on what constitutes an appropriate book, she does not identify a similar potential plurality of authorial intentions. She recognizes that the critic who does the deciding exercises not only their power as adult, but their power as a professional or authority on the subject to ignore or even condemn books considered "unsuitable," but she 
stops short of asking the more crucial question: suitable for what child? Nikolajeva uses the terms "childhood" and "children" as concrete concepts understandable through their opposition to the term adult. Thus the claim that "children had their own special needs" exposes the power imbalance at play. Children's needs are understood as distinct from adult needs, but become homogenized through their difference.

This approach not only relies on the implicit understanding that there is a "real" and homogenous child reader out there who can somehow represent all the ways in which the text might be received, but that the "child" is something directly knowable and recoverable, available unmediated as it were to the adult author or critic, who "vanquishes the necessity for self-reflection on the part of the children's literature critic concerning the construction of meaning and interpretive readings of texts and the world" (Lesnik-Oberstein, Children's Literature 13). The dangers of this assumption to know the child are perhaps best illustrated by an extreme example which demonstrates how short the step is between an absolute claim to knowledge and a moral judgment: "Only a monster would not want to give a child books she will delight in, which will teach her to be good" (Inglis 4). A parent who fails to judge which books will be entertaining yet also teach the child to be "good," and who fails to provide the child with those books, is a monstrous one, a failure of a parent.

This thesis is concerned particularly with the child "in the book," the fictional entity which the adult author creates within a narrative, and which cannot ever be successfully articulated as a "real" child, not least because who or what that "real," textually unbound child might be is arguably unknowable. The adult who imagines 
the fictional child can do so only through the unreliable archives of memory, or through other, equally fictitious and adult-authored representations of the child. I am concerned with this idea of a child which the text attempts to reach and describe. This is a gesture which ultimately fails, and it is the failed "move towards" the child that I see the chosen Golden Age texts as self-consciously working out.

The criticism I have engaged with above, and which critics such as Rose, LesnikOberstein and Nodelman have already engaged with, is unified through claims to know who this child reader is, and, by extension, what that child wants to read and what they should read. These claims point to and also propagate the dichotomies of adult and child, powerful and powerless. The child reader, however, is trapped within the text as firmly as the child characters are: neither can be shown to exist outside of it. While we can speak of an implied child reader, the power of adult over child is in danger of abuse when criticism attempts to speak about and for real child readers. Critics such as Tucker and Inglis assume a "real" child reader where only a textual creation should exist. The primary texts which I will focus on all construct a particularly strong awareness of this fictional child, who is posited as existing outside the narrative, reading it. It is worth considering what sort of readers these texts create, and the extent to which they are framed and "pinned down" by the text.

The sense that a narrative is deliberately and selectively creating its readership is common to nineteenth century novels, and the direct address to this implied reader is a frequent feature, from Austen's and Thackeray's satirical asides to Jane Eyre's "Reader, I married him" and to Middlemarch's continuous addresses to a reader who colludes with the narrator to direct the focus of the narrative as it sweeps over the 
diverse social world of Middlemarch (552). In Eliot's novel, implied reader and narrator assume a collaborative role in constructing the text, one explicated by the narrator in the famous "pier-glass" metaphor:

Your pier-glass or extensive surface of polished steel made to be rubbed by a housemaid, will be minutely and multitudinously scratched in all directions, but place now against it a lighted candle as a centre of illumination, and lo! the scratches will seem to arrange themselves in a fine series of concentric circles around that little sun. It is demonstrable that the scratches are going everywhere impartially, it is only your candle which produces the flattering illusion of a concentric arrangement, its light falling with an exclusive optical selection (264).

The metaphor is used to illuminate Miss Vincy's interpretation of Lydgate's attentions, but it also works to include the implied reader in this egotism and to demonstrate both the impossibility of an impartial view, and the role of the reader in constructing meaning.

Going through my chosen texts in turn, we can see the narrators doing a very similar sort of work in constructing the child who is reading the text. "Fancy curtseying as you're falling through the air! Do you think you could manage it?" Alice in Wonderland's narrator asks the implied child reader, and later explains the caucusrace "as you might like to try the thing yourself some winter day" $(14,25)$. The narrator of The Cuckoo Clock asks the implied child reader "Shall we go inside to see more?" and suggests that, since she has forgotten the name of the arithmetic master, "Suppose we call him Mister Kneebreeches," while the narrator of At the Back of the North Wind frequently breaks off to address the implied child reader 
with explanations and instructions for understanding $(2,15)$. "You must not think it cowardly of Diamond to turn his back to the wind," he abjures, and when Diamond starts crying at having lost North Wind the narrator interjects "of course you, little man, wouldn't have done that!" (23). The opening sentence of North Wind, in fact, creates a self-aware narrator and creates the narrator's implied audience: "I have been asked to tell you about the back of the North Wind" (11). This narrative awareness is repeated in the Princess texts: "I will try to tell you what they are," the narrator observes of the mountains Curdie and his father mine (467).

The Water Babies constructs a far more rigidly defined child reader than that suggested by the Alice texts or The Cuckoo Clock. Not only is this reader addressed consistently as "my dear child," "my dear little man," "my dear little boy," and so on, but the narrator engages the child reader in catechistic dialogue in which the child's lines are written for him $(48,56,8)$. "But a water baby is contrary to nature" this implied child says; to which the narrator replies: "Well, but, my dear little man, you must learn to talk about such things, when you grow older, in a very different way from that" (48). This forms part of an eight-page conversation between the narrator and the implied reader, in which the child reader is finally instructed: “meanwhile, my dear little man, til you know a great deal more about nature than Professor Own and Professor Huxley put together, don't tell me about what cannot be, or fancy that anything is too wonderful to be true" (53).

The adult narrator who addresses the implied child reader of The Water Babies will be particularly important to the reading of that text, but the child reader, how it is addressed and who it is constructed as, is a crucial point of similarity in all eight 
texts. The nineteenth century novel often uses the address to the implied reader and the voice of a narrator; these devices produce an awareness of the narrative's artificial nature, its status as representation or medium, and create collusion between narrator and implied reader. The children's texts I will discuss also function in this way, but the one major difference is that where the novel creates a reader who is an equal of the narrator, at least in the sense that both are adults, the children's book creates a narrator who is adult and an implied reader who is emphatically a child. Thus the Victorian children's book foregrounds the power relationship between the adult and the child.

What the Alice texts, The Water Babies, the Princess texts, The Cuckoo Clock and The Tapestry Room all share is what Sanjay Sircar calls the "“auntly' (or avuncular) voice" (1). He describes this voice as one that "establish[es] a special relationship to the audience" and "employs a broad array of rhetorical strategies to ensure the readers' or listeners' sense of relaxation, equality, and creative - even conspiratorial - involvement" (1). I would contend that the "auntly" voice does indeed seek to achieve all these things, with the one exception of equality. The very term "auntly," although Sircar's, still supposes a relationship of adult authority. The adult will always have power over the child, and in these texts it is strikingly clear that while the narrative voices may exhort the child reader into a range of potentially subversive positions and activities which a parent might not approve of (curtseying in free-fall, for example), they are voices of instruction. They interpellate the reader as a child, and control him or her accordingly. The Water Babies' "dear little man" and North Wind's "of course...you wouldn't have done that" are clear examples of 
adult power being exercised, but even Mrs Molesworth's more subtle suggestions (“shall we go inside?") assume consent and imply an obedient child reader.

Narrative voice is defined by Sircar as that which "describes our sense of a textual speaker who has verbal specificity and yet does not acquire the full-bodied presence of a narrative persona... Narrative voice is created by the selection of words, syntax, register, tone, and attitude toward the story and the audience" (3). The texts with which this thesis engages all share a strong sense of narrative voice, and an equally strong sense of the implied child reader to whom that voice speaks directly. In doing so, these texts bring to the fore the relationship between adult and child, which will be central to my reading, and highlight the constructed nature of audience. In the brief survey of children's literature criticism above, it is apparent that many critics have failed to distinguish between the implied child reader created by the text, and potential, "real" child readers. We should be much less confident in our abilities to speak about the actual children who undoubtedly do, and have, read these texts.

The question of who the implied reader is and whether they can be addressed is an issue for all literary criticism; it is an especially critical issue for children's literary criticism. The child's inherent lack of agency and helplessness is replicated in the readers they are benignly constructed as; and unlike the adult literary critic, the "real" child reader cannot write back against their implied counterpart. It is impossible, of course, to write criticism of children's literature without referring to the implied reader, and I will do so many times in the discussion which follows. My purpose in setting out the issues and critical debates surrounding the implied child reader is twofold. Firstly, in briefly summarizing recent critical approaches, I wish to 
foreground the claims about children which are at stake here. Secondly, I wish to signal a theoretical framework which will inform, and be informed by, my investigation of the ways in which Victorian children's fantasy literature attempts to come to terms with precisely these ideas about problems of knowledge and the ability or inability to write the child. 
Chapter Two

The Romantic Child reconsidered 
Geoffrey Summerfield identifies the defining split between the rigidly didactic Tractarians' conception of childhood and that constructed by the Romantic movement as "the relationship between reason and judgement, on the one hand, and imagination and fancy, on the other" (175). Until relatively recently, the history of the Romantic Child was critically defined as the successful overthrow of reason by fantasy. What is now still broadly understood as the "Romantic Child" is the spiritual, natural, inherently good and innocent being who was famously "Father of the Man" (Wordsworth "My heart leaps up when I behold" 7). This is an entity which criticism has, until very recently, claimed to have arisen out of a contest between the Romantics, particularly Wordsworth and Coleridge, and the Tractarian or Moralist children's authors. This contest was at its heart, this position maintains, one between two opposing philosophers, with followers of the Romantic movement adhering to the work of Rousseau and Émile, in particular, and the Moralist or Tractarian school following the man of reason, John Locke. The Romantics sought to re-write the Moralist account of the child as inherently sinful, mortal and in need of moral and intellectual training in reason, with a more sympathetic account of the child as naturally good, possessed of its own special kind of genius, and less in need of catechizing than of intellectual creative freedom.

The Romantics thus privileged "feeling" over "reason." One of the results of this redefining of the child was the re-establishment of fairy-tales and fantasy as forming part of a valuable children's literature, and the rejection of religious, moralizing and educative works produced by the Tractarians. This dichotomy was until fairly recently approved by both critics of the Romantic era and critics of children's literature. Geoffrey Summerfield and Peter Coveny in their surveys both uphold 
fantasy at the expense of reason, and Geoffrey Summerfield is particularly scathing in his rejection of the moral fables produced by writers such as Maria Edgeworth, Sarah Trimmer and Hesba Stretton. These critics also assume that the innocent Romantic child was inherited wholesale by the Victorians, who merely enlarged and further sentimentalized this child. The Victorian child, they argue, was informed by her Romantic precursor.

Recent criticism by scholars of a more postmodern bent, however, has returned to the works of the largely female Tractarian writers and re-examined the feeling/reason binary, seeking to overturn it. Mitzi Meyers, Patricia Demers and Alan Richardson all argue that the exclusively male Romantic writers reveal a conservative agenda in their insistence on the natural, the authentic and the imaginative as exemplified by fairy-tales, upholding social and gender roles as fixed and eternal. Simultaneously, they uncover in the female Moralists' stories radical, progressive ideas about the child's independence. Essentially, the Moralists wished to prepare the child for an independent rational life, and admit the potential for social change, while the Romantics, in their insistence on the child as a separate, almost solipsistic entity, attempt to fix it in an eternal space that does not allow for progress.

This new criticism challenges the readiness with which earlier critics, such as F.J. Harvey Darton and Summerfield, accepted the Romantics' stipulation that we should prioritize feeling or fantasy over reason, and proposes that this priority conceals a conservative, patriarchal bias, as "from a historicist perspective it becomes evident that...fairy tales could represent a harmless, pacifying alternative to radical intellectualism rather than a threat to moral seriousness" (Richardson 42). The 
authors of moral tales not only resisted this "subtle instrument of socialization" through an insistence on the child's need to be educated, and by extension to have access to the tools of potential social mobility, but in writing about the very children whom Wordsworth is supposed to have willed out of existence, London street arabs, young prostitutes, orphans, and other childish figures of disgust and pity who were marginalized socially and culturally in eighteenth century England, they proposed radical awareness where, as Richardson puts it, Wordsworth chose ideology-proof idealization (48-9).

And yet Romantic literature was no more free from social agenda or politics than the moral tale was void of the giants and fairies so offensive to Locke. Indeed, as Mitzi Myers demonstrates in her examination of Maria Edgeworth's "Simple Susan," the fairy-tale "landscape invested with mythic resonance," the "semi-realistic, semiArcadian idyll now typically associated with William Wordsworth" was co-opted by writers of moral tales and Romantic fantasists alike (99). Neither does the fantasy element of the fairy-tale negate or even entirely obscure the moral or lesson which most contained. "Especially in regard to the fairy-tale," notes Alan Richardson, "it is not always clear where the moral tale leaves off and the fantasy begins" (37).

The division between the two ways of thinking about how the child must be spoken to by the adult author is therefore not as clean as critics like Summerfield implied when they proposed the division between imagination and mental freedom for the Romantic Child, and didactic realism and mental imprisonment for the Moralist child. However, my intention is not to explore the ways in which these superficially antagonistic movements borrow from shared cultural traditions, but rather to 
examine the fractures discernable within the Romantic ideal of the child. I argue that rather than existing as the solitary figure wholly unified within nature so often identified with Wordsworth, the Romantic Child was in fact a multiplicity of children. The experiences and ways of living of the Romantic children, both solitary and communal, rural and urban, were written by adults who constructed the child according to their own purposes, and in this alone these disparate children are unified.

The Romantic Child as exemplified by Wordsworth's Boy of Winander, who delighted in solitary communion with the wild landscapes who "knew him well," communicated alone with the "silent owls" and died "ere he was full twelve years old," is a persistent myth ("There was a Boy" 1, 10, 27). He is a child of Wordsworth's creation: the child who famously came "trailing clouds of glory," and the idyllic life he lived, was based upon Wordsworth's own memories of childhood ("Immortality Ode" 64). It was a version of childhood few other Romantic writers had personal access to. Coleridge wholeheartedly approved of this child yet acknowledged that he himself was raised in the sooty sprawl of London, "and saw nought lovely but the sky and stars" ("Frost at Midnight" 54). Neither was this construction of the Romantic childhood, or even the Romantic movement, as fixed and pervasive as it often appears. Victorian nostalgia for what was considered a preindustrial, pre-urbanised Arcadia not only smoothed over the fissures and anxieties in Romanticism as a movement, but can be argued to have partially created in retrospect the unproblematic and emotionally self-sufficient being which became the designated Romantic Child. 
As Sarah Thornton argues, the Victorian crisis of faith and identity brought about by advances in science and technology necessitated a "reinvention of the self...which needed a focus of emotion which the idea of the child can be said to have gone some way in providing" (123). James Kincaid maintains that the innocent child of nature is largely a late Victorian concoction, while Linda Austin locates the particular form of the Victorian "Romantic Child" as largely arising from a sentimentalized reading of the "Immortality Ode" which ignores the stresses within the poem (Kincaid 72-3; Austin 86). The fracturing and uncertainty as to what the child really is both within the "Immortality Ode" and some other poems of Wordsworth's will be a starting point for my reconsideration of the Romantic Child.

Jeanette Sky writes that "What the Romantics bequeathed to the later nineteenth century was an image of the child as innocence incarnated"; however she also notes that the thinking informing this creation was concerned with control: "The Romantics' idealisation of childhood was...less an act of liberation, and more a conservative reaction to the radical ferment of the 1790s with its unprecedented upsurge in literacy and a hunger for ideas" (366). If the Romantic movement's desire to idealise the child as "innocence incarnated" was motivated by a conservative fear of a radicalised, knowledgeable population, then this itself implies within the Romantic movement an awareness of the child's potential experience and sinfulness. While the Romantics did not simply "bequeath" the Romantic Child to the nineteenth century in a straightforward sense, as it may be argued that the Victorian age also extracted the Romantic Child from the differing and often contradictory ways in which Romanticism talked about childhood and the child, this pervasive and 
enduring idea of the Romantic Child remains one of the primary modes in which to talk about childhood in criticism.

The Romantic model of the child and of children's literature which was inherited but also shaped and uncovered by the Victorians contained within it the trace of an other child, a child who was experienced, worldly, and touched by the same sin which touched the adult. The conservative Romantic agenda which sought to contain the innocent child implicitly refers to the possibility of its opposite, a radical and knowledgeable child. That possibility was articulated directly within the Romantic project by the protesting voices of Blake and Hartley Coleridge, but Wordsworth himself also explored the possibility that children were entirely separate from adults and thus unknowable, even while his poetry also seemed to celebrate and articulate the child. It should not be forgotten that the "Immortality Ode," whilst it does contain Wordsworth's most famous descriptions of the Romantic Child as the immortal "Seer blest!" and "best Philosopher," is primarily a poem about the loss of vision, about how the ravages of time and experience render it harder and harder for the narrator to access his child-self, and how "The things which I have seen I now can see no more" $(114 ; 110 ; 9)$.

While the text's goal may still have been to connect the adult self to the child, there is an underlying uncertainty as to whether it is possible to achieve this. When the poem describes the "four year's Darling" who creates "some little plan or chart, / Some fragment from his dream of human life," we are again confronted with this problem: the adult cannot see into the inner life of the child $(86,90-1)$. What that fragment might be, though no doubt clear to the child, remains wholly unintelligible 
to the adult who tries to interpret it. It may be anything from a "wedding or a festival" to a "mourning or a funeral" (93-4).

In "We Are Seven" the narrator is confronted with the opacity of the child not as something frustrated by memory, but as the inevitable failure of communication between adult and child. The "little cottage girl" simply does not understand the world in the same terms as the narrator (5). In her view, her two siblings' "graves are green, they may be seen" and thus they count as her siblings and she is justified in maintaining "we are seven" despite the persistent attempts of the narrator to catechize her into giving the correct answer that she is one of five $(37,64)$. Eventually, in a fit of exasperation, the narrator shouts at her "But they are dead; those two are dead!” but “"Twas throwing words away; for still / The little Maid would have her will, / And said, 'Nay, we are seven!'” (65; 67-9). Something similar happens in "The Idiot Boy," where Betty Foy's idiot son, missing all night in the forest, is called on to account for his whereabouts. The only answer he will give is, 'The cocks did crow, to-whoo, to-whoo, / And the sun did shine so cold" (460-1). His experience of the world is something fundamentally different from that of his worried mother, it is incommunicable to her, and it is something the narrator seems to approve of: “Thus answered Johnny in his glory, / And that was all his travel's story" (462-3). While it cannot be claimed that Wordsworth's Romantic Child did not exist, or was a figure wholly invented by Victorian or twentieth century social and critical desires, it is possible to read at least an unsettled ambiguity in his poetry as to what this creation was, and whether it was necessarily a stable or accessible thing. 
Hartley Coleridge raises further questions about the Romantic creation of the "favoured Being" and seems to embody, both in his life and his poetry, the extent to which the Romantic Child was divorced from any actual, knowable child (Wordsworth “The Prelude” Book 1 364). The son of Samuel Coleridge, he was also the "designated genius," the son of Romanticism and the living embodiment of the Romantic child (Plotz 191). He was the star of "Frost at Midnight," the sleeping baby who would gain spiritual and intellectual sustenance from the wild landscapes denied to his father. Wordsworth addressed him as a thing too rare for life, exempt from adulthood, for

$$
\begin{aligned}
& \text { Nature will either end thee quite; } \\
& \text { Or, lengthening out thy season of delight, } \\
& \text { Preserve for thee, by individual right, }
\end{aligned}
$$$$
\text { A young lamb's heart among the full-grown flocks. }
$$

("To H.C., Six Years Old" 21-24)

Hartley Coleridge occupied a strange, liminal space during his own time, and continues to do so today. For Andrew Keanie, he straddles uneasily the transition from Romantic to Victorian poetry, figuring both as "the neglected nineteenth century poet" and "the genuine Romantic article," and remaining a minor figure of both movements (55). With the notable exception of Judith Plotz's work, on which this chapter relies rather heavily, his work has not attracted much critical attention beyond the interest of Coleridgeans curious as to what kind of son that unreliable genius created. The word "created" applies in a double sense here, as Samuel Coleridge selected Hartley as the favoured son who would follow in his father's steps, and as "Frost at Midnight" clearly shows, created a textual existence and travel plan for his life before the infant Hartley could do more than sleep at his father's 
side. Hartley was, in his father's words, to "wander like a breeze" and "see and hear / The lovely shapes and sounds intelligible / Of that eternal language," living a life constructed as natural, spiritual, philosophic, and everything that Coleridge senior's childhood "pent 'mid cloisters dim" was not ("Frost at Midnight" 58-9, 55, 53).

When speaking of the personas who inhabit a text, it is of course important to retain a sense of the distinction between an entity which stands in for and fictionalises the "real" author as an "implied author," and between a voice which acts as a narrator and the authors (both implied and "real") with which it must not be confused. Since Barthes' "Death of the Author," in which he proposed that to seek "the explanation of the work... in the man or woman who produced it" was to produce a shallow reading which ignored the interplay of text and reader, to read autobiographically is critically naïve (143). This presents a problem when discussing the poetry of Hartley Coleridge. The implied Hartley, the Hartley in the text, is both an authorial existence and a subject of the text. Much of his poetry concerns this "textual Hartley," which is both a thing of his own creation and one which he extrapolates from both Wordsworth and his father's textual treatment of him.

So Hartley the implied author is constantly signaling towards a range of different Hartleys: selves who exist in others' texts, in his own texts as subject, and selves which rely on autobiography. While Barthes (and many others since) warns us of the dangers of seeking to understand a text through linking biography to textual content, in the case of Hartley Coleridge this is inescapable. Much of his poetry cannot be read except as a response to his father's poems and to the life that was arranged for him in the texts Coleridge senior and Wordsworth created. While retaining an 
awareness of these issues of authorship and narration, in the discussion that follows I simply refer, for the sake of convenience, to "Hartley." I am doing so advisedly, and hope that it will be clear where I am talking about Hartley in a biographical sense, as a construct of someone else's narrative, and when I am referring to an implied author or narrator.

When I refer to this textual biography of Hartley, I speak of the "Faery Voyager" created by Wordsworth, the child of whom his father wrote proud letter after letter to his friends, recounting this profound metaphysical statement said, or that imaginary land brilliantly illustrated ("To H.C., Six Years Old" 5) ${ }^{4}$. That the precocious and charming child Hartley failed to become the brilliant visionary adult Hartley is well documented; Judith Plotz recounts his disappointing life and lays much of the blame on his father's unrealistic expectations that Hartley would be the "test-case" Romantic child and would live out the prophesy articulated in "Frost at Midnight" (Plotz 213-221). Hartley's best-known sonnet, "Long time a child, and still a child," tells of the blighting experience of growing up as his father's son, and as "the firstborn son and heir of English Romanticism" (Plotz 216). In the poem, he finds himself "still a child, when years / Had painted manhood on my cheek" and though grey-haired, is neither "child, nor man, / Nor youth nor sage" (1-2, 9-10). Celebrated as the prodigal son of Romanticism and marveled over as Wordsworth's whirling, rapturous, intuitive child-genius in the flesh, it is with a start that he awakes from this delightful dream "to sleep no more" ("Long time a child" 7). In some sense, despite his enthusiastic belief in the natural childhood of Émile, Coleridge had gone entirely against Rousseau's strictures to avoid creating "infant prodigies" who could

\footnotetext{
${ }^{4}$ Andrew Keanie's article "Hartley Coleridge: Son of the Mariner, King of Ejuxria" surveys both the heights of STC's paternal pride in his genius son, and the cruelty with which he was capable of addressing him.
} 
not grow into intelligent, honourable men. Cast as the eternal child, a Peter Pan figure, it was in some sense inevitable that Hartley's adulthood was a failure.

Hartley's intense awareness of this failure to deliver on his early promise is what drives much of his poetry. "I am a desert, and the kindly sun / On me hath vainly spent his fertile rays," he writes in Sonnet XI, and this theme of time and resources wasted upon a "poor wit" is repeated throughout his writing $(5-6,11)$. His

"Dedicatory Sonnet to S.T. Coleridge" lays a debt of gratitude for "my little art of numbers" (2) at his father's feet; three years later in another sonnet on his "perfect and immortal father" he admits "Thy great Idea was too high a strain / For my infirmity" ("Coleridge the Poet" 13, 11-12). It would be simplistic, however, to read these piteous outbursts of regret purely as self-flagellation. Known as "Hartley" or even "Poor Hartley" by acquaintances and "Li'le Hartley" by country locals all his life, he was designated, almost fetishised by others and himself as eternally childlike (Plotz 199).

It is through this fetishised childhood that Hartley finds a reason for his inability to mature into the Romantic Child's adult heir: he lacks, in spite (or because of) his childish genius, the capacity for growth. Again and again he depicts himself in terms of an otherworldly littleness; unable to grow, he is therefore a creature divorced from normal human experience. He is the "waif of nature," "an "uprooted weed," a "poor elf" or "one leaf trembling on a tree"; a thing without the means of renewal, the fertile mind called upon to perform too early and left barren. For Hartley, the image of the child performs a double role. Not only is it the primary mode in which he speaks of himself, allowing him to remain blameless and childlike among children, 
but it is through addressing children that he finds comfort and solace in the ruin of his adult life.

Thus Hartley writes to child after child: greeting a "sweet girl" on the occasion of her first birthday ("The First Birthday" 1), addressing Mary Ann Green as "Thou purest abstract of humanity" ("To An Infant" XXVII 3) and another unknown baby as "This tiny model of what is to be / A thing that we may love as soon as see" ("To An Infant" XXVIII 2-3). To his god-daughter Caroline Green he wishes "would that I might give thee back, my little one, / But half the good which I derive from thee ("The God-Child" 13-14), and in "The Fourth Birthday" he imagines the comfort a bereaved father derives from the boy whose birth killed his mother, and prays that "Ne'er be thy birthday as a day unblest" (25). Of his sister's twins, who die within an hour of birth, he writes "Sweet buds that not on earth were meant to bloom" ("On My Twin Niece and Nephew" 7) while "Lilly" makes him "scarce believe that "man was made to mourn”" (“To Lilly” 14).

The addresses to these children are similar, and the sentiments expressed often conventional to the point of triteness. Hartley's beloved children are all "sweet" and "merry," or are "stainless" images of innocence and perfection, all with a "claim of grace" ("The God-Child" 4). All offer him the same consoling immersion in infant love. Hartley addresses a variety of children, many of whom are specified in titles or his own end-notes: his god-daughter, his nephew and niece, children of friends, local girls and boys. These specifically named children are unified in their lack of individual detail; though identified as individuals, they are spoken to, or about, as homogeneous, interchangeable. Named they may be, yet they are spoken of as 
childhood "types" or tropes who exemplify childishness while lacking any specific characteristics. Hartley re-uses titles ("To an Infant"); he even reproduces the same poem twice: "The Fourth Birthday" and "To James, Son of T. Jackson, on his Fourth Birthday" both address a little boy whose life has come at the price of a mother's death; both meditate on how long those four years must seem to the child, and how "very little time they seem" to the anxious mourning adults who find comfort in the child's "gushing laughter and transient tears" ("To James" 2, 28).

There is a dual purpose to this seemingly contradictory and reductive exercise of positing irreducible similarity in children who are simultaneously identified as individually real. As Judith Plotz notes, Hartley finds immense comfort in those aspects of infancy - the inarticulate sounds, needs, indiscriminate affection and fears - that are common to all very young children (209). It is the infants' sameness rather than their variety which appeals and consoles. However, what is also discernable within these poems of infancy is something substantially more complicated than simply comfort for a man who casts himself both physically and mentally as a child or as a miniaturized, incomplete adult. It is possible to read in Hartley's poetry a persistent questioning of how far any adult can actually "know" the child and whether there are limits on what can be said about it. Wordsworth's apparent certainty that the child is a fixed and eminently knowable being that can be accessed reliably through the adult memory is sometimes doubtful. But for Hartley, it always is. While Hartley certainly desires the kind of comfort Wordsworth suggests the child might provide, he is more than uncertain as to how reliable this idea of the heavenly child is. 
In Sonnet XXVII, addressed "To an Infant," Hartley appears to agree with Wordsworth's position in the "Immortality Ode" when he states that "thy smile was brought / From some far distant paradise" (4-5). But the sonnet's opening line announces this conceit to be no more than a comforting idea: "Sure "tis a holy and a healing thought" (1). Indeed, the moment of the child's birth is a "doom'd" one: it is fallen the moment it lives, and while Hartley muses frequently on Wordsworth's ideas about pre-existence, imagining that the child's soul existed before birth in "wood, or wild, or sunny stream," he perverts his own attempts to imagine a perfect divine origin. The soul may also have resided in "the Almighty mind / Among the forms of fair and awful things," just as Blake's God is responsible for both the lamb and the tiger (CPW 196-197 in Plotz 209). The child is "a sweet infant mystery," unknowable to adults, just as its origins lie in a mysterious pre-existence that produces not just what is fair but also what is awful (Sonnet XXVVIII 7). Any attempt by the adult author to remember or shed light upon infancy must necessarily be an invention imposed upon the child; indeed the trope of the innocent child itself must be questioned, since

\section{if thou wert so good}

As love conceives thee, thou hadst ne'er been born;

For sure the Lord of Justice never would

Have doomed a loyal spirit to be shorn

Of its immortal glories - never could

Exile perfection to an earth forlorn (Sonnet XXVII 10-14).

For Hartley, desire is not the same as truth. The divine infant is a healing thought, but this cannot be confused with a healing truth. Where Wordsworth proposes an 
uninterrupted line of sight "in a season of calm weather" to "that immortal sea / Which brought us hither" and where "the Children sport upon the shore," Hartley contests rather that the adult creates this scene retrospectively out of his own desire for spiritual reassurance (“Immortality Ode” 165-169). "To a Deaf and Dumb Little Girl" questions in a similar way the extent of adult knowledge of the child, but rather than examine the child as constructed through memory, it looks at the interpretive gap between an adult and a real child, in a similar vein to "We Are Seven" and asks whether the adult can understand or speak for the experiences of a child.

Echoing Donne, the deaf and dumb girl is described as "a loose island on the wide expanse," a being whose inability to communicate aurally or orally makes "Herself her all" and imposes on her a life outside human interaction: she is "Doom'd to behold the universal dance" but never to hear "the music which expounds" the mysterious movements of existence ("To a Deaf and Dumb Little Girl” 1-6). The girl is thus initially framed as isolated and excluded from full participation in life. Yet she does not seem to feel this isolation. She is concerned with her own inner life, "Concentred in her solitary seeing," and it is the adult poet, trying to break through her implacable silence, who feels shut out from some experience he cannot understand (11). The poem is titled as an address to her, but the speaker fails in his effort to do so; all he can attempt is a poem about her. "In vain for her I smooth my antic rhyme; / She cannot hear it" he writes (9-10). If a communication has failed, it is Hartley who feels the loss, rather than the child. Unable to interact with her, he also inevitably fails to convincingly say anything about her. "What can she know of beauty or sublime?" he wonders, but has to pull himself back from statements about the potential poverty of her existence upon beholding her "calm" and peaceful looks, 
and recognizing the fruitlessness of such speculation (12-13). Finally, all he can suppose is that "God must be with her in her solitude!" (14).

A second criticism of the Romantic Child is at work in Hartley's poems. As already noted, when he speaks to and about children, he constantly repeats his material: the terms in which the children are described, the consoling effects they have both on himself and, he imagines, on other adults, and even titles and whole poems are recycled and used to address different children and different events. As Judith Plotz argues, this was about more than a need to immerse himself in consoling, indiscriminate infant love. Evidently, all babies were the same to Hartley; indeed his repetitive descriptions suggest that he saw children as identical copies of one idea of a "Child," stretching the Romantic Child to its logical conclusion ${ }^{5}$. How he describes his children, however, reveals how meagre the content of that child is. Comforting himself with his myriad children, all sweet, merry, full of sudden joy and sudden tears, and all arrived from "the unknown place / Of unborn souls" which, though beyond human imagination, he still hopes is something that might approximate Wordsworth's imperial palace, Hartley enacts the paucity of the Romantic Child's substance ("The First Birth Day" 4-5).

Hartley Coleridge, to a much greater extent than Wordsworth, questions what the Romantic Child that he was supposed to be consists of, and the conclusion of much of his poetry is that its substance is elemental, archetypal, and removed from the reality of any living child. What the life and experiences of a "real" child might be,

\footnotetext{
${ }^{5}$ Plotz argues that Hartley saw in the uniformity of babies "the embodiment of pure Being" (209). While he certainly saw children as identical to a large extent, I would argue that in his writing this uniformity is as much, perhaps more, about articulating the limits of the Romantic Child as it is about celebrating the "attributes of humanity without limiting, frustrating, alienating individuality" as Plotz puts it (209).
} 
he concludes, is beyond any adult comprehension. Even adult memory, for Hartley, is a faulty mechanism which only creates that which we want to remember. Children are opaque, and their inner lives cannot be extracted. As a consequence of this, Hartley can do no more than assume the child's goodness. Even the innocence of the child, perhaps the single most important constitutive (at least according to Rousseau) of childishness, is open to debate. An innocent child is, in fact, a paradox since, as Hartley identifies, "if thou wert so good / As love conceives thee, thou hadst ne'er been born" (Sonnet XXVII 10-11). The child must therefore attain some state of experience in entering the world.

William Blake's Songs of Innocence and Songs of Experience start from this assumption that existing as innocent in the world is impossible. The child is born into an inherently sinful and experienced world and, as such, there are only two modes of existence available: either as knowledgeable, political and historical, or as ignorant and blinded to social reality. The "Introduction" of Songs of Experience is narrated by a voice which is resonant with knowledge and mysticism:

Hear the voice of the Bard!

Who Present Past \& Future sees

Whose ears have heard the Holy Word

That walk'd among the ancient trees (1-5).

This narrator calls himself a bard, an omniscient teller of myth and story; the narrator of the corresponding "Introduction" of Songs of Innocence is a piper who pipes "a song about a Lamb" and sings "songs of happy chear" to please a child on a cloud $(5,10)$. The narrator of this introduction wants only to produce "happy songs, / Every child may joy to hear" $(19,20)$. 
It is a voice which has a simple intent, to entertain children, and it announces that the songs which follow will be similarly entertaining and agenda-free. But already this opening is compromised. The cherub-like child on a cloud has a note of death about him; living children have both feet on the ground. He will be echoed in the Songs of Innocence by the dead sweeps who "rise upon clouds" ("The Chimney Sweeper" SOI 18). When, at the insistence of the child, the narrator writes his happy songs down in a book, this saccharine innocence is problematised further. To write the book, he "pluck'd a hollow reed," "made a rural pen" and "stain'd the water clear" (16-18). The clear, pure water becomes "stain'd" or tainted with writing. Language, the province of the adult, has infected the pure Arcadian landscape of the child, and to write the child is therefore to irreparably mark it with adulthood.

It would appear then that this text follows a Rousseauean logocentrism: there does exist an idea of the child which is prior to writing, and through being written that child is degraded. "God makes all things good, man meddles with them and they become evil" begins Émile, and it seems that the "Introduction" agrees with this conception of the supplement, that which is added to nature, as an artificial evil (5). It is not only the fact that an adult writes the child which is an issue, but that he modifies nature to do so, using unnatural artifice to make his "rural pen." By making his pen and staining the water with its ink, the narrator introduces the pollution of knowledge into an unknowing natural landscape. But the text also performs itself as the writing which "stains the waters clear" or renders them comprehensible, so that while it is a corruption imposed upon the scene, it is also the transformative agent by which the unintelligible is made clear. While language marks the child with 
adultness, it is the only means by which the child can be articulated. The text presents an inescapable paradox: the child, set down in language, cannot exist as a "pure" child or be considered entirely untouched by the adult authority which created its textual existence. At the same time, it is this textual existence which allows the child to be read, and to be intelligible. Without a language in which to write the child, it would not exist for our purposes.

The following discussion takes as a starting point Judith Plotz's observation that the “The Chimney Sweeper” of Songs of Experience is fundamentally “a poem of determinism" which focusses on the sweep's awareness that "his situation has been determined and exploited by his keepers, his parents and their collaborators" (Plotz 100). It is this awareness, she argues, that makes his innocence impossible and marks him as experienced: "Recognising that he is an object among other objects, moved by forces he cannot control, the chimney sweeper of Experience is neither innocent nor invulnerable" (101). Plotz argues that the sweep of Songs of Innocence is "impervious is his innocence," that his very lack of awareness preserves his innocence and "keeps his human heart intact," and this in turn shields him from harm (99). I would argue rather that it is the sweeps' very existence that makes them experienced. The situation of the "innocent" sweep, as Plotz notes, "shames the adult reader" and his ignorance and passivity highlights that situation, but his ignorance does not preclude him from experience. As the "Introduction" of Songs of Innocence makes clear, creation comes at the price of purity, and to be innocent is to be unspeakable. 
The "Introduction" serves as a warning for the reader and a manifesto for the children who populate the two sets of poems. The children of the Songs are touched by adulthood not only through language but through the narratives they live out. They are the casualties of corruption, sin and social breakdown; the world they live in is irredeemably fallen and, as such, their innocence is lost the moment they are born. What the Songs illustrate is the almost grotesque image of the child who is unaware of this on the one hand, and the anger of the child who is aware on the other. The children of the Songs of Innocence are horrific in their naivety; like the sweep who believes that "if all do their duty, they need not fear harm," they are brainwashed by Church doctrine and live lives of poverty, disease and powerlessness ("The Chimney Sweeper" SOI 24). It is their submission and their lack of awareness which make them such disturbing figures. Tom and his fellow sweeps are already harmed; the release they look forward to is Heaven. His counterpart, the sweep of Songs of Experience, knows that the rags he wears are "the clothes of death" and that Heaven, if there is such a thing, is a "heaven of our misery" ("The Chimney Sweeper" SOE 7, 12).

The innocent Tom dreams that thousands of sweepers, Dick Joe Ned \& Jack, Were all of them lock'd up in coffins of black; And by came an Angel who had a bright key, And he opened the coffins and set them all free (11-14).

The black coffins in which the boys are imprisoned echo the narrow, sooty chimneys they are forced to sweep and which will eventually kill them. The Angel with his bright key is a messenger of death, and his message to Tom, that "if he'd be a good 
boy, / he'd have God for his father and never want joy," is an order to uncomplainingly accept this miserable existence which God approves of and will reward (19-20). Tom, like his unnamed mentor, internalizes this message thoroughly, and derives comfort from it: “Tho' the morning was cold, Tom was happy and warm" (23). While his experienced double is all too aware that he is marked with death, the innocent sweep does not appear to realize that his coming reward, to "wash in a river and shine in the Sun" then "rise upon clouds and sport in the wind" can only come at the expense of his life: he will, in fact, receive the ultimate harm in return for accepting his duty $(16,18)$.

The experienced sweep is not named and his humanity has been eroded; he is only "a little black thing," and he not only knows that he has been condemned to an early death, he knows who to blame for this ("The Chimney Sweeper" SOE 1). His parents, who have "gone up to the church to pray," are the responsible parties: "They clothed me in the clothes of death / And taught me to sing the notes of woe" $(4,7-8)$. The Church and the parents are complicit in their hypocrisy; the parents sell the young child into slavery and then praise "God \& his Priest \& King / Who make up a heaven of our misery" and validate the parents' decision (11-12). The unnamed sweep is also very clear as to why it is that his parents have gone to give thanks to God: "because I am happy, \& dance \& sing / They think they have done me no injury" (9-10). It is his performance of the role of childhood through his actions of singing and dancing which condemns him and blinds his parents and the Church to his state of existence. Through playing out a representation of the innocent child which continues to function in ignorance of social realities, the child continues to be harmed by those realities. This sweep is able, however, to articulate the difference: 
although he is able to act out children's games, he is also aware that his childhood does not exist any more.

The angry, knowledgeable sweep who tells his story in response to the narrator's question "Where are thy mother and father" is in charge of his own narrative; the innocent Tom Dacre has his story related by another sweep who is older and more experienced, but who does not question his place in the world (3). It is this sweep who gives Tom's dream the final gloss that "if all do their duty, they need not fear harm" ("The Chimney Sweeper" SOI 24). Tom Dacre's naïve faith in the Church is echoed by the little black boy, who looks forward to death, believing that once in Heaven his skin colour will not matter:

...I say to little English boy;

When I from black and he from white cloud free, And round the tent of God like lambs we joy,

I'll shade him from the heat, till he can bear

To lean in joy upon our father's knee;

And then I'll stand and stroke his silver hair, And be like him and he will then love me

("The Little Black Boy SOI 22-28).

Even in death he will perform the role of servant and inferior, shading the English boy from the heat, but he will be rewarded by the love and recognition he is denied in life. Like Tom Dacre, he has internalized the Church's messages; he accepts that to be black is to be degraded, and that whiteness and light are signs of purity. He identifies his own interior goodness with this binary: "O! my soul is white" "but I am 
black as if bereav'd of light" $(2,4)$ The sweeps, too, must shed their coating of black soot in order to enter heaven. Before they can "rise on clouds," they must "wash in the river," remove the signs of their experience and become little English boys again.

The Songs deal with children who are affected by the world; this is, for Blake, the only possible outcome of existence. The only difference between the two sets of children lies in their awareness of this. This is reflected, in the Songs, not only in the personal narratives of the innocent and experienced children, but through the meditation on the effects language has on the representation of the child, staining it with the voice of the adult. In Hartley Coleridge's poems and those of Wordsworth, the adult narrators do not so much affect the child as bang their heads hopelessly against an impenetrable wall which surrounds it. There is a recognition in their texts that the child is, as Hartley puts it, "a loose island" which can never be reached: the child remains outside of language ("To a Deaf and Dumb Little Girl” 1). The narrator of the "Introduction" to Songs of Experience, however, knows that this is one half of an irreconcilable paradox. It is language which gives us some idea of the child, which needs to struggle towards a representation of that which cannot be represented, and without which there would be no child. In the analysis of Victorian children's texts which follows, all will be seen, in different way, to be struggling with this fundamental problem of writing for and of children. 
Chapter Three

Alice and Curdie: the child in language 
When Alice climbs through the drawing room looking-glass and into what she calls "Looking-glass House", one of the first things she finds is a book which seems to be, she thinks, "all in some language I don't know" (Wonderland 101). But she realises that "it's a Looking-glass book, of course! And if I hold it up to a glass, the words will all go the right way again" (102). However, when she does so, the poem that she reads seems hardly more intelligible. It is of course "Jabberwocky," a poem which has, like several other poems, characters and quotations in the two Alice texts, taken on an independent life of its own outside the context of the narrative it is part of, Through the Looking-glass, and What Alice Found There. Just over a quarter of the entire poem consists of "nonsense" words made up by Carroll; making the words "go the right way" does not initially appear to be of much use in deciphering the text which famously begins:

Twas brillig, and the slithy toves

Did gyre and gimble in the wabe;

All mimsy were the borogroves,

And the mome raths outgrabe (102).

Alice struggles to make some kind of meaning from this, objecting that "it seems to fill my head with ideas - only I don't exactly know what they are!" before concluding for the time being that "somebody killed something: that's clear at any rate" (103). However later on she has an encounter with Humpty Dumpty, who provides her with a set of meanings which Alice is content to accept in the absence of any others. Her dialogue with Humpty Dumpty is a famous episode in the text; famous at least among academics of the philosophy of language, since it is "often cited as defining an extreme limit in semantic theory" (Hancher 49). While he is 
happy to help Alice with the "hard words" of "Jabberwocky," Humpty Dumpty is also a linguistic outlaw, assigning his own private meanings arbitrarily and "reduc[ing] to absurdity the nominalist and subjectivist proposal that words derive their meanings from the intentions of the persons who utter them" (Hancher 49). The following much-quoted passage illustrates this:

"I don't know what you mean by 'glory,"” Alice said. Humpty Dumpty smiled contemptuously. "Of course you don't - till I tell you. I meant 'there's a nice knock-down argument for you!'” But 'glory' doesn't mean 'a nice knock-down argument,"' Alice objected. "When I use a word," Humpty Dumpty said, in rather a scornful tone, "it means just what I choose it to mean - neither more nor less.”

"The question is," said Alice, "whether you can make words mean so many different things."

"The question is," said Humpty Dumpty, "which is to be master that's all" (142).

While this exchange is terribly puzzling for poor Alice, she doesn't seem to question in any way Humpty Dumpty's right or ability to bend language to his will; in fact, she accepts him as a sort of semantic guide and requests, since "You seem very clever at explaining words, Sir," that he explain "Jabberwocky" (143). This he proceeds to do, and while the meanings he allocates to the "nonsense" words may seem just as arbitrary as the meanings he calls on known English words to perform, they do in fact conform to the basic rules of grammar which inform "Jabberwocky" and which preserve it from complete unintelligibility. Thus he informs Alice that “'Brillig' means four o'clock in the afternoon - the time when you begin broiling things for dinner," “'toves' are something like badgers - they're something like 
lizards - and they're something like corkscrews" and "To 'gyre' is to go round and round like a gyroscope. To 'gimble' is to make holes like a gimlet' (143-4).

His definitions may be completely random, or they may be based on loose sound and word associations, but Humpty Dumpty is still submissive to the rules which govern syntax: he observes for example that "gyre" and "gimble" must be verbs given that their association with the "slithy toves" as something they "did" suggests that they are actions carried out by the toves. Alice accepts his definitions as from someone who has power to wield language in a way that she does not. Two levels of power can therefore be discerned. Humpty Dumpty is subordinate to syntactical rules, but only in this instance where he interprets another's words. Alice subordinates herself to Humpty Dumpty and does not question his definitions even though earlier she objects to his use of the word "glory" to mean "a nice knock-down argument." What this exchange points to is Alice's recognition that even while he employs a confusing, secretive and entirely personal system of generating meaning which bears no resemblance to the language she knows and uses, Humpty Dumpty appears to Alice to have some right to do so. He is an adult figure, and it is to his status as adult and the authority which that status confers that she submits.

Alice's exchange with Humpty Dumpty, and in fact most of her exchanges with the inhabitants of Wonderland and Looking-glass Land, are marked by this power imbalance which is worked out at the level of language. Adult ciphers, they control the rules of language and meaning in their worlds, and Alice, ignorant of these rules, must inevitably come out second best in the debates in which she is engaged. The Alice texts are littered with utterances like that of the Hatter, which "seemed to have 
no meaning in it, and yet...was certainly English", and the entire narrative may be considered a complex linguistic joke at the expense of Alice and the reader, neither of whom possess the requisite knowledge to make sense (52). My concern here is not so much to unravel the games played or the semantic theories critics have attributed various episodes to mocking, but rather to examine how power is distributed through the ability to play such games with language. In one sense, Humpty Dumpty is right when he states that the only question, when it comes to the creation of meaning, is "which is to be master." Alice's (correct) belief that he is forcing words into bearing meanings they cannot carry is ultimately of no consequence in Wonderland; she is powerless as both outsider and child. Secondly, and of greater concern to my overall thesis, I hope to show that the adult creatures of the Alice texts demonstrate, through their mastery of an alien language game and their ability to define Alice at will, that the child is defined and controlled through language.

Nonsense language, parody and crucially, fantasy, may, according to Linda Shires, "be considered similar in one respect: they explode or transgress the frame of the 'real' and thus open up a space of uncertainty. Pushing towards the realm of nonsignification where nothing is stable, these forms open a gap between signifier and signified which makes a definite meaning or absolute reality impossible to attain" (267). The Alice texts, rich in all three of those modes, certainly resist definite meaning for the reader or critic; they also resist definition by Alice. However, they are not meaning-less, in the same way that nonsense language is not a language of a literal lack of sense. To arrive at a fixed meaning for "Jabberwocky" is not possible, but neither can we claim that it is "without sense," since it can be read. Something truly without sense could not be read; it would be an arbitrary collection of words or 
letters; it would not be language. Perhaps what we can say instead is that parody, fantasy and nonsense, in transgressing the frame of "the real," establish new relationships between signifier and signified that readers, and adventurers from the "real" world, like Alice, cannot comprehend.

Alice, a child who is supposed to be within a dream of a surreal and anarchic world (and the question of who it is who does the dreaming is an important one here), finds that even in the wildest lands of fantasy, certain rules must be adhered to. In order for the narrative to retain some sort of meaning, however open-ended or nonsensical that meaning might appear, it must be constructed according to known rules of syntax and grammar. May, commenting on Wittgenstein's theory of "language games," notes that "a language whose rules cannot be followed or can be broken at whim is an impossible language" which creates "an impossible life" or "a form of madness" (Wittgenstein's Reflection 82). Certainly there is much that Alice experiences which suggests that Wonderland and Looking-glass Land are places of madness, but, as May points out, the Cheshire Cat uses a logical argument to prove his assertion that everyone is mad in Wonderland (Wittgenstein's Reflection 82). So while there is madness, there is also logic, and there are rules governing the language games: they are merely rules which are so alien to Alice and to readers accustomed to the "normal" rules of the English language that neither can participate in the game.

The texts gift linguistic control to the creatures who inhabit Wonderland and Looking-glass Land, in doing so defining them as adult ciphers in the absence of any human adults. The creatures use this control in a very adult way too; they exercise 
the adult's right to tell the child what she is. Perhaps the most obvious instance of imposed definition is Alice's exchange with the pigeon. Alice has just swallowed a portion of the Caterpillar's mushroom which has caused her neck to lengthen like a snake's body, and she finds herself attacked by a pigeon who insists that Alice is a “Serpent" intent on stealing her eggs (40). Alice's attempts to convince the pigeon otherwise are unsuccessful, partly due to the fact that the physical and mental manipulations and changes wrought on her by Wonderland have rendered her ambivalent about her own identity:

"But I'm not a serpent, I tell you!" said Alice. "I'm a-I'm a--"

“Well! What are you?" said the Pigeon. "I can see you're trying to invent something!"

"I- I'm a little girl," said Alice, rather doubtfully, as she remembered the number of changes she had gone through, that day.

“A likely story indeed!" said the Pigeon in a tone of the deepest contempt (41).

When Alice tries to prove her argument by telling the pigeon that "little girls eat eggs quite as much as serpents do," the pigeon merely expands her definition of Alice as serpent to include all other little girls. "I don't believe it," she replies, "but if they do, why then they're a kind of serpent, that's all I can say" (41). The pigeon, a mother and an adult, reserves the right to define little girls, or children, by her own reductive logic: serpents eat eggs, so if little girls eat eggs, then they must be serpents too. 
Far more serious for Alice and her sense of identity is the existentially terrifying news supplied by Tweedledum and Tweedledee that she is not real; she is merely a part of the Red King's dream:

“He's dreaming now," said Tweedledee: "and what do you think he's dreaming about?"

Alice said "Nobody can guess that."

“Why, about you!' Tweedledee exclaimed, clapping his hands triumphantly.

"And if he left off dreaming about you, where do you suppose you'd be?"

"Where I am now, of course," said Alice.

“Not you!" Tweedledee retorted contemptuously. "You'd be nowhere.

Why, you're only a sort of thing in his dream!"

"If that there King was to wake," added Tweedledum, "you'd go out bang! - just like a candle!” (125)

When Alice tries to quiet the pair for fear they should wake the King, Tweedledum remarks, “'it's no use your talking about waking him...when you're only one of the things in his dream. You know very well you're not real.' 'I am real!' said Alice, and began to cry"” (125-6).

This conversation embodies the problem of the adult writing the child into fiction: the child, or the idea of the child, only exists so long as the author "keeps dreaming." Alice, the subject of the Red King's dream will "go out" when he "leaves off." At the narrative's end it is suggested that instead of "going out" she merely wakes up into the framing narrative of reality; but this also supposes then that it is Alice who did the dreaming. She wonders out loud "who it was who dreamed it all...it must have been either me or the Red King. He was part of my dream of course - but then I 
was part of his dream too!" (180) Nina Auerbach claims that Looking-glass Land is possibly the Red King's dream, a mirroring of Wonderland about which there is "no equivocation" as to who dreamed it: "the dainty child carries the threatening world of Wonderland within her" (32).

While Alice does indeed seem to wake up, the Red King never does, that we know of: I would suggest that he remains dreaming until the narrative's end. With his tasselled red night-cap, snoring in a rumpled heap, he does not make for a kingly figure, but he does share a comic affinity with the other inventor in the narrative, the rather more hopeless White Knight. Both these absurd characters stand, in different ways, for the creative authority of the narrative, and Alice does indeed "go out" when that authority ceases the narrative. What Tweedledum and Tweedledee call to the attention of Alice and the implied reader is Alice's fictional and subordinate status: she exists only as long as the narrative is sustained by the author who created it.

Even while these texts attempt to create for her a dreamscape in which the child, asleep and inexperienced, experiences freedom and bizarre adventure permissible only in fantasy, they confirm that the child is defined through and in language, and as such, there are ordering limits on what she may dream. In order to retain any chance of intelligibility, language remains ultimately dependent on adult-imposed structures, and it is this language which describes the child in the text. The pigeon's definition of Alice as a serpent is allowed as viable in Wonderland logic, just as Humpty Dumpty's linguistic contortions trump Alice's knowledge of how words mean, and the Mad Hatter's "logic in excess" defeats her so utterly that the only 
thing to do is to get up and leave a conversation she cannot hope to participate meaningfully in (May Wittgenstein's Reflection 83). These instances of adult control and definition of language and of the idea of what a child is point towards the Tweedledum and Tweedledee episode, where lies the heart of the problem. In stating that the child Alice is being dreamed by the adult Red King, and that she will cease to exist when he ceases to dream, the text articulates the dilemma shared by these Golden Age narratives: a child written by an adult can never be entirely childlike or innocent.

An adult author, Carroll writes a child who will also cease when his narrative ends. The child only exists in an intelligible way through language, which is rule-bound and above all the province of the adult. What the text exposes here is the totality with which the idea of the child is subsumed within the adult who creates it. Adults then, as the arbiters of language, taint the child irrevocably. The distribution of power between the adult and the child is unequal; the adult has the power to write and to define the child while the child remains a passive thing described within a text, and in doing so the experienced adult leaves on this defined child the trace of their adultness, their experience and knowledge of the world. The very notion of the "innocent child" so dear to the adult imagination is thus revealed as an impossibility: returning again to Blake, we find that to write the child is to "stain" it with our adultness.

This is approaching something very like Derrida's famous statement "There is nothing outside of the text [there is no outside-text; il n'y a pas de hors-texte]" (Of Grammatology 158). I take this to mean not that nothing literally exists outside of 
writing, or the text, but rather that we are unable to access the "outside", to reach through writing and access a pure point of origin. Following this line, the idea of the child as a free and truly innocent entity may exist as a potentiality, as a concept that could occur, but for the reader, for the text and for the author the practical outcome is that the "child" does not exist; there is no child "outside the text." Perry Nodelman formulates it in this way:

As Derrida shows, there never was an "other" - never anything before writing, never a prior, truer mode of speaking or thinking except the ones we invent as a means of belittling our adult selves; and similarly, there surely never was a childhood, in the sense of something surer and safer and happier than the world we perceive as adults. In privileging childhood as this sort of "other," we misrepresent and belittle what we are; more significantly, we belittle childhood and allow ourselves to ignore our actual knowledge of real children (Hidden Meaning 147).

I would argue however, that this evaluation undermines itself in its belief that there is still knowledge of "real children" which can be retrieved and which dependence on the privileging of childhood as an innocence so total as to be outside and before writing ignores; that in fact "real children" can be known and accessed in some way outside of the texts they are represented in. Our "actual knowledge of real children" is also recorded, coded and interpreted through language, and therefore to define some point at which we can declare knowledge "actual" and real in a way writing is not, is problematic. While Nodelman is right to say that there never was an "other", never anything before writing, he does not recognise that this lack of an outside is precisely what makes impossible knowledge of how and what real children are. As 
Karín Lesnik-Oberstein formulates it, in this view of childhood, children "are seen primarily as being constituted by, and constituting, sets of meanings in language [emphasis added] (Childhood and Textuality 2). Turning now to MacDonald's Princess narratives, we shall see what happens when a text attempts to gift linguistic control to the child, to explore, in effect, the opposite of what the Alice texts assert: whether the child can define itself using language which breaks free from adult conventions.

George MacDonald's At the Back of the North Wind and the Princess texts (The Princess and the Goblin and The Princess and Curdie) share a similar concern with whether the child in the text can be successfully realised as an entity free from adult intervention. However, where the Alice texts stop short of imagining a truly "childlike" language, instead exploring the power language confers on the adult, MacDonald's texts actually attempt to create that language, allowing the child in the text to define itself, and in the case of Curdie, to wield considerable power, using his own childlike language.

Curdie is a miner boy who works in the mountain beside which is the castle where Princess Irene lives. This mountain is overrun with goblins, or "cobs," as the miners call them, who are a constant source of fear to those who live in the castle and the surrounding lands. The miners, however, despite encountering the goblins frequently in their excavations, are less perturbed by their malicious presence than those who exist above the ground, because they know how to deal with them: the goblins "hated verse of every kind, and some kinds they could not endure at all" (North Wind 334). The reason for this, the narrator supposes, is that "they could not make 
any themselves"; Curdie believes that "hav[ing] no more voice than a crow," the cobs "don't like other people to sing" $(334 ; 325)$. But the kind of song which drives a goblin away must not only be sung or chanted, but it must rhyme, it appears. Within the range of rhyming songs, too, some are more efficacious than others: "there were certain old rhymes which were very effectual, yet it was well known that a new rhyme, if of the right sort, was even more distasteful to them" $(325,334)$. Among the miners, Curdie is respected as a man, despite being just "about twelve years old," because he is particularly good at making up the right sort of new verses, and although the narrative states that most of the miners had some skill in these rhymes, Curdie is the only person whose chants appear in the text (326).

Curdie is in fact in the rather strange position of being, in both of the Princess texts, the sole active and effectual character. Both narratives are full of powerless, foolish or ineffectual adults. Princess Irene's "king-papa" is absent in The Princess and the Goblin, and maintained in a drugged sleep by a scheming doctor and Lord Chamberlain in The Princess and Curdie, her nurse Lootie is a foolish fearful woman who endangers the princess and goes off in faints or hysterics when danger threatens, and the entire population of Gwntystorm, the king's capital city, is under the spell of "commerce and self interest," and "lying and selfishness and inhospitality and dishonesty [are] everywhere" (529; 562). Curdie's parents are wise and thoughtful, but unlike Curdie cannot cross between classes, and so must remain in their cottage, functioning as providers of comfort, advice and shelter to Curdie, powerless to physically intervene. His father Peter does, in the final chapters of The Princess and Curdie, run to Gwyntystorm to help his boy, but when he arrives "by this time the battle was over" and his gesture is merely symbolic (616). 
The exception to this adult impotence is the mysterious and ancient "Queen Irene" who secretly inhabits the attic of the castle, lives off pigeon eggs and is Princess Irene's "great-great-grandmother" and more than a hundred years old (311). She shares much in common with the ancient "North Wind" of At The Back of the North Wind; both are omniscient and magical women who are at once ancient and grey, young and beautiful. Both work, although Queen Irene to a far greater extent than the hugely powerful North Wind, through manipulating others, so that while Queen Irene provides the means (a magic thread which guides Curdie and Irene safely from the mines; the hideous but powerful and loyal beast Lina who is Curdie's companion when he goes to Gwyntystorm) and the directions for all to turn out well, it is Curdie who saves the day every time. What he possesses which the other adults do not, and which, interestingly, Princess Irene also does not, is the ability to manipulate and use a language which is incomprehensible to adults.

Indeed, "adult" language is a problematic concept in the Princess texts; more often than not it fails as communication. Irene's attempts to explain to Lootie her discovery of her great great grandmother are met with the remark "it is not at all becoming in a princess to tell stories and expect to be believed just because she is a princess" (315). Irene remarks later, when Lootie refuses to believe she was chased out of her room by the goblins' deformed domestic creatures, "When I tell you the truth...you say to me Don't tell stories: it seems I must tell stories before you will believe me" (429). In the second Princess narrative, Curdie sees the one honest person in the palace, a housemaid, abused for telling the truth about a page stealing a pie. "'It is hard not to be believed just because one speaks the truth,' said the girl, 
'but that seems reason enough with some people...the truth is a strange thing here, and they don't know it when they see it"' (573). Even Curdie finds that the king's guards will not believe him when he tries to warn of an impending goblin attack: "the man concluded that Curdie was only raving still, and tried to coax him into holding his tongue...[Curdie] now felt in his turn what it was not to be believed" (434-5).

Where correct language fails, though, another sort of language succeeds, and is immensely powerful. The language the miners use against the goblins has the power to physically control. The rhymes Curdie chants are in this sense magic spells or incantations which send the goblins running. The power derives from the verses' repetition of sounds, whether rhyme or metre. Curdie first enters the narrative to save the princess and her nurse from the goblins when they have stayed out after dark on the mountain, and he defeats them with the following verse:

Hush! scush! scurry!

There you go in a hurry!

Gobble! gobble! goblin!

There you go a wobblin';

Hobble, hobble, hobblin';

Cobble! cobble! cobblin’!

Hob-bob-goblin! --- Huuuuuh! (325)

This is not Carollinian invented nonsense. With the exception of the word "scush," these words are part of the English language of MacDonald's time, but they seem to be used purely for the purposes of rhythm, so that the effect is one of sound and metre and rhyme, and meaning seems evacuated, except for the order to "go in a 
hurry." However, just as in the Alice texts there are limits on what meanings can be made, here there are limits on how meaningless a rhyme can be. Curdie's rhymes do fail him once. When he is trapped in the goblin hall under the mountain, he attempts to drive them off with

Thirty, forty, fifty -

You're all so puff-and-snifty!

Forty, fifty, sixty -

Beast and man so mixty!

Fifty, sixty, seventy -

Mixty, maxty, leaventy!

Sixty, seventy, eighty -

All your cheeks so slaty!

Seventy, eighty, ninety,

All your hands so flinty!

Eighty, ninety, hundred,

Altogether dundred! (393-4)

The narrator remarks "whether it was that the rhyming words were most of them no words at all...I cannot tell, but the moment the rhyme was over, they crowded on him again" (394). Curdie's rhymes, it appears, cannot depart too far from "proper" English or they will lose their efficacy.

Verse of this sort has, of course, no effect at all on human adults. At the narrative's start, the narrator explains that 
at one time [the goblins] lived above ground, and were very like other people. But for some reason or other, concerning which there were different legendary theories...they had all taken refuge in the subterranean caverns... Those who had caught sight of them said that they had greatly altered in the course of generations; and no wonder, seeing they lived away from the sun, in cold and wet and dark places (302).

Later, when explaining how the goblins came to have domestic animals, the narrator, remarking on their "subnatural ugliness," notes that "in the case of these the human resemblance had greatly increased: while their owners had sunk towards them, they had risen towards their owners" $(367,368)$. The goblins are subhuman; their generations underground have caused them to devolve, and presumably the ability to make verse or sing is one of the human qualities they have lost. Curdie believes it is for this reason that they hate verse. However, the goblins clearly have more than a jealous dislike of verse; they actually fear it, suggesting that they recognise in verse a form of magical, incantatory power to compel or harm. Belief in magic or spells belongs in this text to children, and the goblins are, in fact, childlike. They have the same fears as children, fears that are regarded as irrational or nonsensical by the adults of the text and only Curdie's childish language can defeat them. Their domesticated animals are described as "creatures - but so grotesque and misshapen as to be more like a child's drawings on his slate than anything natural," and the king's guardsmen who see them find that "to not one...they could give a name" $(365,366)$. The goblins and their ilk appear beyond the reach of adult language; it can neither name nor affect them. 
In George MacDonald's At the Back of the North Wind, the child protagonist Diamond attempts to craft his own language just as Curdie does. He succeeds where Curdie actually fails, but as communication his language does not work, because in creating a language which is truly childish, he creates something which cannot be understood. His verses break down into repetitive fragments, and while Diamond and his baby brother derive meaning and happiness from it, what that meaning is remains opaque. The narrative only ever supplies one example of this verse, which is so long and repetitive that a contained, representative sample cannot really be given:

I know a river

whose waters run asleep

run run ever

singing in the shallows

dumb in the hollows...

...always and ever

growing and blowing

for fast as the sheep

awake or asleep

crop them and crop them

they cannot stop them

but up they creep

and on they go blowing...

...by the singing river

that sings for ever

and the sheep and the lambs

are merry for ever 
because the river

sings and they drink it...

(110-113).

The narrator can only be sure of what Diamond "thought afterwards that he had heard," which is invariably not quite right, because "it was so near sense that he thought it could not really be what they did sing" $(110,192)$. Even the verses that Diamond spontaneously constructs and then forgets are just poor reproductions of songs which cannot be rendered in "sense" or the English language at all. Just as happens with "Jabberwocky," absolute nonsense can only be gestured towards.

Curdie's language also fails as a genuine language of the child, and eventually fails to protect him from the goblins. The reason it fails as protection is that it becomes too nonsensical and "un-adult." When his rhymes rely on words which are "no words at all" they do not affect the goblins and he pulls back to rely on more sensible words (394). The goblins are childlike; they can approximate something of the child, but cannot really stand in for it. Curdie's verses, too, can come close to a child language and defeat the goblins, but cannot pass beyond the rules of adult language without becoming powerless and meaningless. In order to be effective, his verses must retain some grammatical iron, just as Curdie himself, although a child, is only able to function as the hero through acting as an adult. In a world where the real adults are impotent, the potential for a child saviour is undermined by the adult roles he must adopt: royal advisor, provider, spy, warrior, judge and finally, husband. Even while, paradoxically, there are no powerful adults in the Princess narratives, to have power is to be adult-like. 
Diamond finds that no written or spoken language is adequate to reproduce the song he knows, and so it is consequently possessed of a theoretical existence, beyond the text and beyond understanding. The moment it is articulated it becomes what it is not, and is infected with the "sense" of language. Curdie must not only behave as an adult but also keep his language within the rules in order to possess any power at all, while the Alice texts reject the possibility that the child can even exist without an adult to articulate it. These narratives are all experimenting with the linguistic boundaries between sense and non-sense, straining towards a way of representing the child on the child's own terms, in the child's own language. And while the child in the text may be approached, given freedom or given power, these things can happen only at the behest of the adult author. The child in language remains inseparable from the adult who writes it; the child beyond the text remains theoretical and unreachable. 
Chapter Four

Tom and Diamond: the child and death 
Turning now from the idea of the child whom the author attempts to reach in language, I wish to explore what happens when this idea of a child is placed in a narrative which would have been familiar to a Victorian audience, the child's death. Death and the process of dying presents, for narrative, similar issues to those already raised with regards to writing the child. Both are beyond language; there is a double wall. The child death-bed scene is one recurrent in Victorian literature: Dickens, for example, perfected the art of the poignant, heartbreaking child death scene in The Old Curiosity Shop and Dombey and Son, but the image would also have been recognisable as one derived from the many Victorian "comfort books" which presented highly stylised scenes of dying children released from the world into the care of Heaven, and which were intended as comfort for bereaved parents.

Kimberley Reynolds and Paul Yates read the Victorian "textual desire to kill children... as a way of keeping them and protecting them; halting the ageing process and preventing children from becoming less perfect" (167). Slightly twisted echoes of Blake's account of the corrupting world can be read in the comfort book, as well as an investment in the Romantic Child so complete that death was construed, as Reynolds and Yates point out, as preferable to the degeneracy of growth (167). Sarah Thornton points out, speaking about Dickens, that to write the child is also to kill it: "Paul, Nell and Em'ly... are caught by the pen in one pose and labelled like specimens in a jar and thus denied any other form of existence" (144). More tellingly, Little Em'ly of David Copperfield is first imagined by the narrator as having died when still a child, implying "it would have been far better for her to die as an innocent child than to live to become a sexually erring woman," and then suffers a textual death, banished from the narrative to Australia (Thornton 145). The 
Romantic Child, that entity with which much Victorian writing about children is obsessed, was already perfected, and thus positive growth was impossible. Death often appears as the only narrative option to ensure the preservation of that perfection.

The Victorian comfort books, like Dickens' novels, were potentially available to readers of all ages, but their intended audience was the grieving parents left behind, and as Reynolds and Yates point out, they functioned by creating a discourse intended to be consolatory, where the dying children are escaping a wicked world and actually, in the words of Frederic Faber's “The Weeping Angel” (1858), "like to die" (cited in Reynolds \& Yates 165). The preoccupation of these narratives was not so much what occurred after death, since entry to Heaven was assured for the angelic children who populate the comfort book, but how to die a "good" death. The child's death in the comfort book is invariably sweet, pious, transcendental and painless, and is both consolatory and instructive for those left behind. While Victorian narratives written explicitly for child could function in this mode too, fantasy literature, already concerned with articulating the unreal, actually accompanied its fictional children into death. As will be discussed later with regard to the "return journey" device, Victorian fantasies (with the exception of those such as MacDonald's Princess texts which are set in a hermetically sealed world from which there is no route to the "real" world) frequently engage with death in order to imagine the fantasy landscape. It is through dreams and hallucinatory, life-threatening fevers that the child in the text is transported to the alternate worlds of Wonderland, Tapestry Land and the land at the North Wind's back. 
This chapter will examine two texts which undertake to imagine what lies after life and to try and describe it: Charles Kingsley's The Water Babies, and George MacDonald's At the Back of the North Wind. Both these texts are set in a "real" England, and both use death as the gateway into fantasy, The Water Babies through death itself, and North Wind through a prolonged and ultimately deadly illness. However, these texts are doing more than simply using child death as a springboard. With varying degrees of awareness, they interrogate the meaning and possibility of writing death itself, in much the same way as the Alice and Princess texts work to expose the tensions in writing the child. Just as the child cannot be intelligibly articulated without the contaminating presence of adult language, to write death in these two narratives proves impossible. Either language breaks down and loses all meaning, just as Curdie's language does, or death becomes articulated through its opposite, life, in the same way that the child Alice can only be written by the adult.

The Water Babies takes an ambivalent stance toward the possibility of knowing what happens after the child dies; the story is understood through a filter of the evolutionary theories of the day and on one level can be read as an account of Tom's "self-evolution" from a beast-like savage to a human soul, and rather more nebulously, to "a great man of science" (The Water Babies 223). Tom's “evolution" takes place after he is washed out of his body, or drowns, and therefore knowledge has both a scientific and a religious, baptismal sense in this narrative. But this is a narrative jammed with entities, especially adult ones, characterised by ignorance disguised as pseudo-knowledge, and such "facts" as are thrown to the reader are invariably nonsensical or wrong. While the narrative voice appears to make very definite claims to know what happens to Tom and to all children, it is no more 
trustworthy than the characters it denounces as wrong or misguided. The Water Babies parodies the great nineteenth century scientific debates yet also enacts a debate within itself in which narrative exposes the untrustworthiness of a narrator who declares himself, however jokingly, the possessor of the:

one true,

$$
\begin{aligned}
& \text { orthodox, } \text { inductive, } \\
& \text { rational, deductive, } \\
& \text { philosophical, seductive, } \\
& \text { logical, } \quad \text { productive, } \\
& \text { irrefragable, salutary, } \\
& \text { nominalistic, comfortable, } \\
& \text { realistic, } \\
& \text { and on-all-accounts-to-be-received } \\
& \text { doctrine of this wonderful fairytale (58). }
\end{aligned}
$$

The Water Babies makes and then undermines its own claims to "know." George MacDonald's At the Back of the North Wind is far less ambiguous about whether language can or cannot describe the child's death. According to North Wind, it cannot, and a recurring motif of the narrative is that of the failed linguistic reach towards some kind of fixed meaning or articulation of death. While North Wind makes explicit a continual reaching towards and drawing back from the child on the other side of death, The Water Babies hides this cyclical gesturing inside a narrative frame and voice that appears at least to be much more confident in the ability of language to articulate what might lie after death. The question most often posed about this text is that of whether or not Tom the chimney sweep actually dies. Like 
the narrator of North Wind, the narrator of The Water Babies can be read as nodding towards a second implied reader, an adult who sees through the fantastic account of Tom's "rebirth" or reincarnation as a water baby, and subsequent journey through stages of what might be considered purgatory to a heaven of sorts as a similar device for allegorising the death of a child.

The problems raised by this seeming nod to the understanding adult, who despite the narrator's reassuring asides to the child reader understands that Tom is indeed drowned, centre around the fact that the narrative sets up adults in the story as fundamentally mistaken and as sources of misleading information. Professor Ptthmllnsprts is a figure who allows the narrator to satirize some of the scientific beliefs and practices of the day and their reception, particularly the public outcry at Charles Darwin's Origin of Species, but also to make a claim about the moral danger of scientific narrow-mindedness. The Professor is well versed in the theories of Darwin, having declared that "apes had hippopotamus majors in their brains just as men have", which, the narrator comments, is a "very wrong and dangerous thing, at which everyone will be very much shocked" as "the one true, certain, final, and allimportant difference between you and an ape is, that you have a hippopotamus major in your brain, and it has none" $(102,103)$. The narrative voice is ironic; he tells the implied child reader that "you may think that there are other more important differences between you and an ape, such as being able to speak, and make machines, and know right from wrong, and say your prayers, and other little matters of that kind; but that is a child's fancy, my dear" (102). 
That "child's fancy" is, this heavily satirical tone implies, the correct view to take. Professor Ptthmllnsprts has gone, the narrator continues,

I am sorry to say, even further than that, for he had read... a paper, which assured every one who found himself the better or wiser for the news, that there were not, never had been, and never could be, any rational or half-rational beings except men anywhere, anywhen, or anyhow; that nymphs, satyrs, fauns, inui, dwarfs, trolls, elves, gnomes, fairies....angels, archangels, imps, bogies or worse, were nothing at all, and pure bosh and wind (103).

In response to his pupil Ellie's wish that there were water babies and mermen, the Professor gives her a "succinct compendium of his famous paper at the British Association, in a form suited for the youthful mind" and eventually, fed up with her persistent questioning of why there are no water babies, "answered quite sharply - "Because there ain't"; however no sooner has he done so than he catches Tom the water baby in his collector's net (104).

The Professor, according to the narrator, is given to absolute statements about how the world is ordered and what is and is not possible: in his paper, for instance, he is reported to have said not only that there "were not" any of the following list of creatures, but there "never had been, and never could be," and not only "anywhere" but "anywhen and anyhow." This exhaustive statement is deflated by the very unscientific way in which the Professor sums up his argument and his discussion with Ellie: that such beliefs are "bosh," and that there are no water babies simply "Because there ain't." The narrator confides in the implied child reader that this reply "was not even good English, my dear 
little boy," colluding in their exclusive knowledge of the Professor's foolishness (104). The reader, however, is only in on this secret because they have been treated to a sort of sermon on the dangers of following the Professor's type of scientific thought too closely. The narrative supplies an interruption from this implied child who objects "But there are no such things as water-babies," to which the narrator responds: "How do you know that? Have you been there to see?...no one has a right to say that no water-babies exist, till they have seen no water-babies existing; which is quite a different thing, mind, from not seeing water-babies" (47).

The narrator has an overt respect for the scientific minds of the day; Huxley, Darwin, Owen and Murchison are among the names of "great men whom good boys are taught to respect" and the narrator declares himself sure they would never make the Professor's mistake of saying “That cannot exist. That is contrary to nature" (48). However, the Professor's "hippopotamus major" is a play on the hippocampus minor, which Owen declared unique to the human brain, thus separating humans from simians, and which Huxley argued was present in simian brains, and thus proved "the impossibility of erecting any cerebral barrier between man and the apes" (cited. in Straley 583). That respect is also tempered by a distaste or disapproval on the narrator's part for what he sees as science's tendency to define humanity as mere anatomy (Straley 584).

The Professor, on catching Tom, exclaims "What a large pink Holothurian; with hands, too! It must be connected with Synapta...It actually has eyes!... Why it must be a Cephalopod!" (105). He falls back on the same ploy used by the 
doctors who treat his ensuing madness; hiding a failing in his real knowledge ("real" at least within the narrative's definition) with an overwhelming glut of scientific false knowledge. The doctors who treat him diagnose his illness, in "true medical language, one half bad Latin, the other half worse Greek" as "Bumpsterhausen's blue follicles" (109). The list of treatments they prescribe takes up four pages, and includes "Bullyings," "Suffumigations of sulphur," "Pure Bosh," "the Poughkeepsie Seer his Prophesies" and "The distilled liquor of addled eggs" $(111,113,114)$. None of these succeed, for the Professor's madness has been caused by a fairy who punishes him "because he did not believe in a water-baby when he saw it" by making him "believe in worse things" (109). The Professor's sin, and that of all the scientists, is not just that of narrow-mindedness, refusing to see what the world is really like for "fear of spoiling their theories," but of covering up their ignorance with "long words" $(108,109)$.

If adults cannot be relied on to provide truthful and accurate information, then the narrative itself cannot be trusted. It is narrated by a voice which takes care to construct itself as adult, to speak down to the child reader in such a way as to imply that the relationship is one of power in which the narrator not only supplies the narrative, but anticipates the child's responses and can rebut them. "And of course Tom married Ellie!" the implied child exclaims, to which the narrator replies, "My dear child, what a silly notion! Don't you know that no one ever marries in a fairy tale, under the rank of a prince or princess?" (222) This adult narrator wields such a firm grip over the narrative that he is unwilling to leave the reader's reaction to a reader, instead building the process by which the narrative is read into the text, 
attempting to exert authorial control over narrative content but also over reception and interpretation. So there is a logical problem: in this text, adults cannot understand or explain, and yet the narrator is an adult. The narrative supplied, therefore, while continually making claims for knowledge, and particularly the claim to know what it is that happens after Tom's "death," must therefore be similarly limited and at a loss to account for what occurs by its very "adultness."

Tom, like Diamond, falls ill, and in a fever, goes down to a stream to bathe. And while the narrator is careful to point out to the implied child reader that the adults were "utterly mistaken," they still "found a black thing in the water, and said it was Tom's body, and that he had been drowned" (53). What really happened, the narrator explains, is that "the fairies had washed him...in the swift river, so thoroughly, that not only his dirt, but his whole husk and shell, had been washed quite off him" and Tom had become a water baby (54). This "real Tom" is equated to the notion of a soul when the narrator instructs the reader to "believe the one true...doctrine of this wonderful fairy tale; which is, that your soul makes your body, just as a snail makes his shell" (58).

Tom is therefore able to retain some form of altered existence despite the destruction of his physical self because his soul remains. The process he then undertakes in order to "evolve" from his current status as "a poor little heathen" who is "but a savage now, and like the beasts which perish" is the allegorical journey of a soul towards Heaven, a narrative device which echoes Dante's Divine Comedy, a work which is also important in North Wind as an insufficient account from one who has visited the afterlife $(40,58)$. Unlike Dante, however, who travels as a sort of tourist through the 
regions of Hell, Purgatory and Paradise, Tom must actively evolve, physically and morally, until he is good enough to "go home on Sundays" with Ellie (222).

The "going home on Sundays" presents something of a logical issue. Ellie, the little girl who teaches Tom to be better once he has made it to St. Brandan's Isle, home of the water babies, appears to be dead: after falling and hitting her head at the seaside, the fairies came flying in at the window, and brought her such a pretty pair of wings, that she could not help putting them on; and she flew with them out of the window, and over the land, and over the sea, and up through the clouds (108).

Tom is eager to know where his new playmate goes on Sundays, but, pressed to explain what it is like, Ellie can tell nothing about the place, except to say that "it was worth all the rest of the world put together" (150). Diamond, the protagonist of At the Back of the North Wind, experiences a similar inability to explain the heaven he visits. A paradox is operating here, where heaven is beyond language, but death is not. While these texts may be producing a proper Christian modesty and humility which makes speculation as to the true nature of heaven blasphemous or at least spiritually arrogant, death, and in Tom's case, purgatory, are seen as distinct from heaven and therefore open to articulation. The problem raised by the acceptability of describing death is that the texts have no language in which to do so except the language of life. This points to a reason for the inability to describe heaven; there is no appropriate language with which to speak about the final and absolute barrier from which there will be no return and which cannot be tainted with life. 
Even while Tom, having battled his way to the Other-end-of-Nowhere where Mother Carey makes all the species in the world out of seawater and forced his old master Grimes to see the error of his ways, is finally allowed to go home on Sundays with Ellie, he is also simultaneously "quite alive, I assure you, still” (142). Tom's final reward, after going home with Ellie "on Sundays, and sometimes on weekdays, too" is to become "a great man of science" who "knows everything about everything, except why a hen's egg don't turn into a crocodile, and one or two other little things which no one will know till the coming of the Cocqcigrues" (222). So Tom's reward for successfully evolving his soul from that of a beast to a man and advancing through the stages of purgatory is not to reach heaven, but to receive life. His body mirrors his evolution: whilst a sweep, he is described as resembling "a dead pig," "a black ape," and "a small black gorilla" $(9,21,23)$. When he falls into the stream, he thinks "I will be a fish" but is reincarnated as an "eft" (39). From that state he evolves into a water baby, and then finally into a "tall man" (221).

Mother Carey explains near the narrative's start that Tom is "but a savage now, and like the beasts which perish; and from the beasts which perish he must learn" (40). This suggests that Tom, although similar, is not completely bestial, and therefore has the chance of improvement. But it also indicates that death is not his lot, since he is not a beast, who will die. The bestial part of Tom must perish, but he will live. The crossing over into the realm of death is in fact a transition to a better form of living, one which assures life where his past existence as beast-like little boy would have led him to death. Ellie's reward, which is heaven, remains outside the bounds of language, and while Tom is granted a great future by the narrative, what becomes of Ellie is never stated, other than the fact that she doesn't marry Tom. Tom's “death" 
is described in the terms of life; eventually his death becomes life. Ellie, dying a different death, and existing in a place for which there are no words, disappears from the text.

The final scene in At the Back of the North Wind takes its inspiration from a comfort book tableau: the peaceful, almost transcendental deathbed of a child. The boy Diamond, referred to throughout the narrative as "God's baby," both as a reflection of other characters' assumptions that he "had a tile loose" and as a pointer to his all too obvious fate, is discovered by the narrator, who until this final point in the narrative has remained an authorial voice, without direct participation in the story (268). Climbing the stairs to Diamond's room at the very top of his master's house, the narrator observes the following scene:

A lovely figure, white and almost as clear as alabaster, was lying on the bed. I saw at once how it was. They thought he was dead. I knew that he had gone to the back of the north wind (292).

What is at the back of the north wind is a land which is perfect, heavenly, and beyond all "proper" language. Like Ellie, who visits a similarly indescribable place on Sundays, Diamond finds it "very hard to tell" what the land is like; but unlike her he attempts to construct a language with which he can give some account of the place, since regular English will not do (91).

As this land is one which is behind and also through the North Wind, Diamond must pass through her body, which is resting in a land of icebergs and mountains. The North Wind to Diamond looks "dead at last" for she sits so still and seems to 
embody this Arctic landscape she resides in (89). "Her face was white as the snow, her eyes were as blue as the air in the ice-cave, and her hair hung down straight, like icicles. She had on a greenish robe, like the colour in the hollows of a glacier seen from far off" (89). Diamond must walk directly through her heart, into a "cold that stung him like fire" until "he fainted and fell...[and] rolled over the threshold" (90). It is not difficult to read this landscape of pristine ice and whiteness as one of greater purity than the warmer world to the South, and the path through the heart of the North Wind as the final purifying rite which the soul most undergo to reach the afterlife. This painful crossing over is a cleansing transition from the corporeal world into the world at the back of the North Wind. Instead of the purging fire which Dante experiences, this is a state of such intense cold it is burning, and whereas "in common faints all grows black about you, [Diamond] felt swallowed up in whiteness" (90).

Dante's Divine Comedy is an important source here; the narrative presents it as one of only two reliable accounts of heaven. He is renamed "Durante" in this narrative, which means "Lasting, for his books will last as long as there are enough men in the world worthy of having them" (91). The narrator opens his account of what Diamond experiences at the North Wind's back by explaining that "we have different reports of the place from the most trustworthy people" (91). The two accounts he relates are those of Dante and the poem Kilmeny written by "a Scotch shepherd who died not forty years ago": James Hogg (90). Both of these, he says, know more about the place than Herodotus, who he states at the very beginning of the story "had not got the right account of the place" (11). Why might Herodotus have got the wrong account? According to the narrator, Herodotus reported that the 
people who inhabited this land "were so comfortable that they could not bear it any longer, and drowned themselves" (11). Certainly this does not tally with Dante's view of the heavenly afterlife, nor with Kilmeny, who found herself in "a land of love of love and a land of light / Withouten sun, or moon, or night" (cited in North Wind 92). Both were unwilling to depart the land, both returned there later in their right times. Herodotus is of course a pagan, a pre-Christian author, and perhaps this accounts for why a narrative with an implicitly Christian understanding of the afterlife might discount his report.

On their return, all three adventurers in the afterlife struggle to adequately describe it: they find that words will not suffice. Dante says that "Passing beyond the human cannot be / worded, let Glaucus serve as simile - until grace grant you the experience" (Canto 1, "Paradiso" 70-2). Kilmeny is doubly speechless. Her experience is related by Hogg, who says that "Kilmeny had been she knew not where, / And Kilmeny had seen what she could not declare" (cited in North Wind 92). The description that follows therefore must be the reporter's inference. From Kilmeny's fractured accounts the narrator of the poem attempts to assimilate an entire vision. Diamond experiences a similar double-silencing, as his story is related through the filter of the narrator, who, in admitting that this is "the most difficult part of my story" exposes the inherent problem in representing another's story (91). "And why should I not know as much about this part as about any other part?" he asks, and answers himself that it is because "I could know nothing about the story except as Diamond had told it...[and] when he came back, he had forgotten a great deal, and what he did remember was very hard to tell" (91). 
This point about the inability to sufficiently explain or make understood death and the afterlife raises two issues which are keys to the narrative's position on death and on the life of the child in relation to the adult world. To the implied adult reader, these adventures with the North Wind and his stay in the strange land might have a darker meaning, one that is only explicitly voiced once by his mother when he awakes from his stay at the back of the North Wind to find her weeping over him and sobbing, "Oh, Diamond, my darling! you have been so ill!” (101). The North Wind and Diamond's night time adventures are the hallucinatory dreams of a little boy who to an adult reader is dying, in the same way as Tom's aquatic journey might be part of the afterlife of a little boy who has drowned. When Diamond wakes after the North Wind's first visit, he is inclined to believe he has had a "curious dream," except that "it did not look altogether like a dream" (28). While Diamond is lost in these vivid hallucinations, his parents' employers find him apparently sleepwalking.

While on this level the story is one of an angelic child who brushes with death more and more frequently until he is eventually taken to the land at the North Wind's back permanently, the text is engaged with a more complex issue than allegorising the child's journey to the afterlife. In order to unpick the statement the text is making about death and our ability to know it in any meaningful way, we must turn to the importance placed on speech acts. Diamond finds he has the same problem as that of Dante and Hogg's Kilmeny: experience of the afterlife, or heaven, cannot be explicated in any way that is comprehensible to those who have not been there. Death is fundamentally beyond language, or, more particularly, it is beyond logical, linear, "adult" language. The only words Diamond can bring back from the North Wind's back are nonsense rhymes that are derived, he believes, from the tune the 
river there sang. When his mother discovers a book of rhymes on the beach while Diamond convalesces, she breaks off reading because "this is such nonsense!" (110). But Diamond insists she read it, and what he hears is "almost the very tune [the river] used to sing" (116).

But the narrator interjects to remind us again of the uncertainty of words when he notes that:

I do not exactly know what the mother read, but this is what Diamond heard, or thought afterwards that he had heard. He was, however, as I have said, very sleepy, and when he thought he understood the verses he may have only been dreaming better ones (116).

So it is only in a state somewhere between consciousness and unconsciousness that Diamond can hear the words the river sang, and these words are unable to be reliably related to the reader or even understood. Again, the narrative uses a double silence or filter to challenge the idea that words are what they say they are, or that they are fixed in any way. The mother reads but cannot understand, Diamond hears and understands but his account is untranslatable and the narrator himself is not even confident that he has been told the original version, if an "original," stable version exists, which seems doubtful. Later the narrator tells us that it is his own impression that every time when Diamond slept well and remembered nothing about it in the morning, he had been all that night at the back of the north wind... [and] always when he woke ...there was a something in his mind...the last far-off sounds of the river...or some of the words of the endless song his mother 
had read to him on the seashore... When he knew he was coming awake, he would sometimes try hard to keep hold of the words of what seemed a new song, one he had not heard before - a song in which the words and the music somehow appeared to be all one; but even when he thought he had got them well fixed in his mind ...one line faded away out of it, and then another, and then another (124).

The true nature of the river's song is "nonsense." The words (if that is what they are, for the text seems to point towards some composite carrier of meaning that is simultaneously word, song, rhythm and light) do not mean anything when taken away from the place that exists after death, and cannot be successfully translated into adult language. However, as much as their reproduction proves slippery to Diamond, as he tries again and again to sing the song to his baby brother, he derives some subconscious or inexplicable meaning from their essence, as does the baby who gets, we are told, "all the good in the world out of it," though it was "such nonsense to those that couldn't understand it!" (126). Death cannot be understood, but in placing Diamond's account of the place alongside that of Dante and Kilmeny, MacDonald places the child alongside a select few who can come anywhere near an understanding: the poets and artists of the world.

Diamond is ranked with the great artists as someone capable of seeing truly into the place past death, and this links him with those who are able to experience death as creation. Even the great artists, however, cannot tell what they find there. Diamond is an innocent child, at least within the terms of innocence described by the Victorian comfort book: he is very literally too good for the world and so is taken back to 
Heaven. Throughout the narrative, when he is not with the North Wind, Diamond is engaged in heroically good deeds. He nurses the baby of a drunken cabman and sets him on the correct moral path through example, drives his father's cab and earns the family a wage when his father is ill, reunites a young man supposed dead with his sweetheart and saves the life of his friend Nanny the street-sweeper when she is dying of fever. These acts, while appreciated, only seem to encourage the general opinion that Diamond is not intended for the world: he is, the drunken cabman says, "an angel come down on his own business" but also, Nanny says, "not right in the head" $(180,149)$.

This raises an interesting problem. On the one hand this position agrees with the comfort book ideal of the child who has a nearness and potential to reach Heaven that the adult lacks, as a being inherently more pure and uncorrupted than the adult, who has been irreparably spoiled through a longer existence in the sinful world. Certainly Diamond is cast in this mould. He is also, however, a figure of experience or knowledge. His journeys to the North Wind's back have given him an understanding which others lack. His friend Nanny, too tainted by the world, is also given a dream by the North Wind, but she later dismisses it: "I never dreamed but that one, and it was nonsense enough, I'm sure" (275). Nanny is one of Diamond's doubles; she functions as his opposite. Diamond's attempts to explain to her about the North Wind fail: Nanny "said she wasn't such a flat as to believe all that bosh" (49). Nanny is experienced in the wrong way; "wrong" for this narrative at least. Like Blake's experienced chimney sweep, she has to struggle in poverty and is too worldly to believe in any kind of salvation. Diamond's kind of experience arises 
from his worldly innocence and capacity to believe; he is the innocent sweep who trusts in God.

The character of Mr. Raymond functions as another one of Diamond's doubles. Where Nanny is his experienced child double, Mr Raymond, who is a writer of poetry and fairytales, is his creative double. He alone recognises Diamond's special qualities, until the unnamed narrator decides to enter the narrative frame at the very end of the story. "'I expect the child's a genius,' the poet said to himself, 'and that's what makes people think him silly"" (170). Mr Raymond, though he does not know it, receives at least some of his stories directly from the North Wind. Diamond in some sense acts as his medium, singing songs when on a trip with the North Wind to a sick lady, who will "never forget the meaning of them; and... never be able to remember the words of them" (288). Diamond intuitively understands the role he has played in this exchange and Mr. Raymond's closeness to the North Wind's land, for he exclaims "If she sees them in Mr. Raymond's book, it will puzzle her, wont' it?", recognising that Mr Raymond is a receptor and he is a conduit of the North Wind's "nonsense" rhymes (288). Mr Raymond is aligned as an artist with Dante and Hogg, and unlike them he does manage to say something about the North Wind, but he does it unconsciously, and he does it in Diamond's child language. As representation, it still fails.

By claiming for the child a knowledge that is shared only with the world's artists, the narrative marks the knowledgeable yet innocent child with adulthood. The artist is someone who by definition is experienced in a way that other people are not. They "see into the life of things"; and to be named an artist is almost exclusively to be an adult (Wordsworth Tintern Abbey 49). So by placing the child and the artist together 
in their ability to approximate an understanding of death, the ultimate and final experience, the narrative positions the child as a figure who, like the artist, attempts to make clear or articulate that which would otherwise be beyond articulation. Recalling Blake's introduction to the Songs of Innocence, where the speaker announces that he will "stain the waters clear" with his "rural pen", this placing of the child and the artist at the boundaries of experience carries with it its own denial. The artist makes "clear" that which cannot otherwise be understood, but in taking the inexplicable and attempting to render it in language, that which is narrated is irrevocably tainted or "stained" by the language which seeks to describe it. The child, like the artist, the narrative claims, is also able to understand that which is not understandable, but cannot translate that understanding into narrative except as a device used by the artist.

Diamond's inability to sufficiently describe the words he has learnt from the river at the North Wind's back in a way that has meaning for adults exposes the problem of using the child as a holder of meaning in this way. A "real" child cannot describe this special awareness; and it is the adult who imposes on the child the possibility of its even possessing this awareness. Thus a creation like Diamond who does know these unutterable secrets and attempts to communicate them will fail, because, as the narrator of North Wind ultimately recognises, he is a child created out of the adult desire to know that which is beyond knowledge, and to tell that which is beyond language. A fictional child remains an adult construction, and his language taints just as adult language does. 
There is a second problem facing this textual desire to articulate death, which The Water Babies shares. When a childish, nonsense language fails in intelligibility, the narrative turns to a language which is understood, the language of life. Life and death and the slippery realm between the two cannot be separated, and the two opposites bleed into each other. Death becomes described in terms of life. This is best understood by turning to an adult fantasy novel by the same author, written much later in 1895. Lilith concludes with a famous quotation from the German philosopher Novalis: "Our life is no dream, but it should be and will perhaps become one" (cited in Lilith 274). One of the major philosophical concerns of Lilith is to explore this shadowy territory between what is and is not reality; or rather, which is the dream. The protagonist of Lilith, suffering like Diamond a near-fatal illness, experiences something which may or may not be the afterlife: a dream so strong and beautiful that he awakes unable to tell if "that last waking also was in the dream" or if he has "come awake too soon" (273).

Throughout Lilith Mr Raven, the custodian of the boundary between the two states, refers to dying as a process of "waking" or "coming alive" into death, a transition into a reality that is purer and more real than what we believe is living, and the narrative is littered with those who have failed to die "properly" or "wake" into death. If that "waking" into death "was itself but a dream, surely it was a dream of a better waking yet to come" the narrator and protagonist Mr Vane comforts himself, "and I have not been the sport of a false vision. Such a dream must have yet lovelier truth at the heart of its dreaming" (273). The dreamscape into which the narrator falls in his fever is reached through a mirror. This mirror both does and does not reflect back what it sees at certain moments. Sometimes Mr Vane sees only his own 
reflection, and sometimes he sees in it the wild moor landscape of the other world. Mirrors are doors but they also make doubles, and they destabilise what may be considered reality. Just as two mirrors opposite each other will produce an endless proliferation of images, so the endless refraction of the narrator back and forth through landscapes both mental and physical bleeds the two together, until elements from the dreamscape/afterlife are able to move freely between both.

This doubling creates not only a fluidity between life and death, dream and reality, but splits the self. Like Diamond, Mr Vane lies ill in bed while he hallucinates. But implicit in the two narratives is the idea made explicit by the Novalis quotation. The hallucinations, if that is what they are, are sufficiently vivid to cause their dreamers to question which is the reality. This creates essentially two selves: one who journeys through the outer reaches of experience and one who remains, as all good children should, safely tucked up in bed. Mr Vane, upon recovering, must wait until he wakes "at last into that life, which, as a mother her child, carries this life in its bosom" (273). He is too old, too experienced to deserve his child-wife Lona who awaits him in death, and must wait out his life. Diamond however is more recently come from death, which is both a wild landscape and an inner world, and thus at the end of North Wind finds it all too easy to finally sever his knowledgeable, spiritually experienced self from his innocent and childish corporeal self.

This is on a most basic level the division between the body and the soul, itself a double which is only one of a "proliferation of dualities: light and darkness, consciousness and unconsciousness, positive and negative, mind and matter...good and evil, Heaven and Hell, God and the Devil" (Herdman 1). These dualities, 
Herdman notes, are a fundamental part of human existence. We see both in the exterior world and within ourselves endless potential for division, and this potential is often thought of as being of particular interest to the nineteenth century mind (Herdman 1). The Picture of Dorian Grey and The Strange Case of Dr. Jekyll and Mr. Hyde are two later texts which come immediately to mind; both are concerned in different ways with man's potential doubleness, with the realisation, as Dr Jekyll puts it, that "man is not truly one but truly two" (Dr. Jekyll and Mr. Hyde 59) These texts, however, are concerned with exploring the gothic horrors and explicating the moral ambiguity of the division between good and evil, or in the case of Dorian Grey, between outer good and inner evil, which are housed within a human frame. While the MacDonald texts are concerned with man's duality, in this case of the body and the soul, the interest lies, following Novalis, in how to re-integrate the two. It is only in death, Lilith argues, that the body and soul are reunited, and the soul begins to live in a way that is more truly "real" than its earthly existence.

Novalis, who believed events of chance and miracles were the revelation of God's interference in the universe, and complementary to rather than contradictory of the laws of nature, finds that in miraculous words, creative words that bring something out of nothing, a transformation or "flame" takes place which synthesises (if only momentarily) two antithetical states: "body and soul, being and non-being, something and nothing" (Pfefferkorn 37). Novalis places the creative word of the poet magician in the paradigm of the creative word of God, marking this miraculous event as the site both of a union between states and a transformation to a new state (Pfefferkorn 37). Lilith and North Wind are concerned less with articulating the poetics of creation, but the narratives take from Novalis the desire to reintegrate two 
opposing states, and reframes this not as a desire, but as truth: one cannot be successfully articulated except by speaking of the other. To talk meaningfully of death requires the language of the living, and this collapses the division between the two. It is helpful at this point to refer back to Derrida's claim, as I read it, that nothing outside the text can be reached or known. Both North Wind and The Water Babies find that language can do no more than gesture towards, or approach death, through a variety of strategies. And yet both these texts are explicitly concerned with what occurs in an afterlife. For death to remain within the text and avoid banishment to the regions beyond language which cannot be shown to exist, it must be described in terms of life, its double.

Mr. Raven articulates this in Lilith with his statement that the act of dying is not a passive role, but one that must be actively undertaken by the dying person in order to die properly and reach what lies behind the mirror. Dying is in fact a creative, rather than a destructive act, and reveals, in both Lilith and North Wind, a life or world which is more "real." The North Wind explains to Diamond, when he longs to return to the land at her back, that he hasn't really seen it yet. "What did I see then?" he asks, and she replies, "Only a picture of it. The real country at my real back is ever so much more beautiful than that. You shall see it one day - perhaps before very long" (282). She also reveals that the words to the songs he heard the river sing, and the boy-angels' song, which he has failed to hold onto, will become crystal clear once he reaches the land at her back. It is due to the fact that Diamond has not yet encountered the "real" land at her back that he can only bring back scraps of rhyme which are impoverished when compared to what he "really" heard. Death is framed as an encounter with the real, and it is its "realness" which accounts for its unintelligibility. 
In both The Water Babies and At the Back of the North Wind, the narratives encounter the same barriers to accurate representation in their attempts to write death. While the question of whether or not Tom dies or experiences some form of reincarnation is arguably far more ambiguous than Diamond's transition from the world, both narratives arrive at a position where death or the afterlife is literally unspeakable. The attempt to do so must result in a failure either in language or in authority. The controlling adult narrator of The Water Babies undermines his own claims for power and knowledge in a narrative where adults are fundamentally untrustworthy and ignorant, and when Ellie does arrive from "home," the narrator is as silent as she is about the nature of that place. Where the adult fails the child can perhaps succeed, but Diamond's own language which he brings back from behind the North Wind can do no more than gesture loosely towards the real meaning. In absence of any other meaningful way to speak about death, both narratives refer back to life in an attempt to create meaning.

The child death, whether glorified in the comfort book, or allegorised in the fantasy narrative, occupies a strange position where it is both a common part of Victorian narratives, and a thing which, like the child, cannot be truly written. Diamond's “childish" language fails just as Curdie's does; falling outside the limits of "adult" or proper language, it cannot work as a communication. Both narratives attempt a new form of language which might allow the child to represent itself, and both ultimately recognise that such a language is incomprehensible. The alternative, in both texts, becomes to use the language of life in order to write death. Alice is defined and ordered about by adult ciphers, and demonstrates that the child is understood through the adult. Just as the taint of the sign "adult" cannot be removed from the sign "child," death cannot be written about with referring to life in order to describe it. 
The two sign pairs work as opposites, without which the other cannot be understood, but the gap between each is also collapsed. In these two texts, the child is the adult, death is life. The child, and its death, are concepts that cannot be imagined or articulated without their polluting opposites, and when the attempt is made, language disappears. 
Chapter Five

Griselda, Jeanne and Hugh reach the limits of fantasy: the return journey 
The "return journey" is a common motif of children's fantasy; the child in the text and, vicariously, the child reader, are allowed to adventure into unknown, wild, and potentially dangerous territory and to be returned safely at the narrative's end to a familiar setting. What the trip into a fantastic or unknown world symbolises, however, or what purpose it serves is difficult to pin down. It is the fact of the "return" to normality which renders this device so ambiguous. The Water Babies and At the Back of the North Wind, while using the journey into a fantasy or dream world to very different ends, are both emphatic in their insistence that such a process is one from which a return cannot be made. Fantasy is an agent of change. Diamond's circulations back and forth rehearse the return, but eventually it is in dreamland or death that he belongs, while Tom's eventual and highly ambiguous entry into the world is as a man of science, a direct result of his moral and physical growth as a water baby, and one far removed from his former life as a chimney-sweep.

The return, however, is problematic, since whatever lessons learned or social or psychological concerns are worked out in the fantasy, the child is returned to the reality from which it came: things have not changed. Sarah Gilead, discussing this problem of what to do with the return, wonders:

From the vantage point of the return, is the fantasy a socialising, ego-forming expression of anxieties, fears or grievances? Or is it a stimulus to subversive desires or cognitions and hence a threat to socialisation? Does the fantasy plot yield knowledge, consolation, or moral significance and thus fit the concept of children's literature as comforting and educative...Does the frame, as a "safe" 
container, enable the fantasy to challenge the norms of reality?" (278).

The fantasy framed by departure and return to normality may work in any of these ways. What is consistent, however, is that the fantasy works upon the child who experiences it, and whether they derive growth, understanding, moral awareness or a safety-valve for antisocial desires from the experience, the return is made to a reality that has remained unchanged. In this sense, whether the fantasy journey endorses behaviour that is anarchic or desires which are unsanctioned by society, or puts the protagonist through challenges designed to socialise in the "real" world, the child returning must remain in a reality which is fixed. They may choose to adapt or not, but the world in which they belong will not adapt to fit their transformative experiences. U. C. Knoeflmacher notes that the "decorous and lady-like women who dominated the field of Victorian children's literature" express something of a paradox in their writing, since "the mode of fantasy also freed the same aggressive impulses that their fictions ostensibly tried to domesticate" (14). He argues that writing fantasy, for women such as Mrs Molesworth, whose texts The Cuckoo Clock and The Tapestry Room this chapter will discuss, was a way to "turn their own satiric energies against the deficiencies or complacencies of a society that frowned on female anger" while outwardly functioning as narratives of socialisation (14-15).

This discussion will not take up that specific issue of female aggression, and nor do I intend to take up any issues of authorial intent. Instead I wish to focus on this idea that fantasy, and the return in particular, was a way of allowing the child to covertly escape social norms and pressures, and in doing so, to exist for a limited time in a space unaffected by adult desires and meaning. I will argue that the return actually 
amplifies the impossibility of achieving this, not merely through the very fact of the return, in which the "real world" has the "last word," as it were, but because, as I will show, the fantasy cannot occur in a space entirely free from adult intervention. Just as the adult is constantly and unshakeably present in the language, so the idea of an adult presence is constantly present in the narrative, in the form of a guide or mentor figure The presence of the adult in the return fantasy sets limits upon to what extent the child can have a truly anarchic and unrestricted experience, since the adult guide constantly explains, limits and instructs how to proceed in worlds that appear initially lawless.

Viewed in this way, the return journey into fantasy becomes a cyclical gesture of the sort that North Wind, The Water Babies and the Alice texts practise in language. Instead of being worked out at the linguistic level however, the return is made part of a narrative, and enacts at the level of plot this reaching towards an idea of the child. The return journey, in other words, is an attempt to grasp or articulate this "child" through first setting up a representation of the real world, with the associated known social structures, and then striking out from that representation of the real into a representation of fantasy land, which may be governed by rules of its own, but which seems a strange and lawless place. It is in the wild and unsocialised spaces of fantasy that the child's inner life might be explored, and the idea of what a child might do if free from adult rules pondered.

However, while this remains a theoretical possibility, what actually happens in the journey into fantasy is quite the opposite. The child is accompanied by adult figures, and while they may be helpful or downright useless, they still signal that it is 
impossible to imagine a child without a mediating adult. The return from this place, therefore, acts in the same way as MacDonald's "breakdowns" in meaning, his gaps between the word and the possibility of its being understood. The return is a retreat, an admission that narrative fails just as language does to say what the child really is, that it will always be understood through the eyes and the idea of the adult. In delivering the child safely back to the reality from where it was taken, the return proposes that there is no child who can be successfully articulated other than as a socialised being, something understood through the adult culture that it inhabits and which shapes it.

In Mrs Molesworth's The Cuckoo Clock, characters seem trapped inside repetitive cycles of history, unable to act in ways that have not been previously rehearsed ${ }^{6}$. Change has a deceptive quality in this narrative. In the opening description of the house and garden to which Griselda is sent to live,

There was a colony of rooks in this old garden. Year after year they held their parliaments and cawed and chattered and fussed; year after year they built their nests and hatched their eggs; year after year, I suppose, the old ones gradually died off and the young ones took their place, though, but for knowing that this must be so, no one would have suspected it, for to all appearances the rooks were always the same- ever and always the same (The Cuckoo Clock 1).

\footnotetext{
${ }^{6}$ For the following discussion of change, "seeming" and lack of change in The Cuckoo Clock I am indebted to Dr. Karin Lesnik-Oberstein and members of the Children's Literature Master's course at the University of Reading. This potential reading of the text was discussed in a seminar I participated in on 12 November 2009
} 
The narrator posits that change must occur, for time passes and rooks are not immortal, yet that italicised "suppose" suggests that although the narrator is aware that both the passage of time and the birth and death of rooks are things that "must be so," the evidence of appearances, that the rooks were "ever and always the same" is almost more convincing.

The way things appear is more important in this narrative than the way they really are. The description of the changing yet unchanged rooks could serve as a sort of blueprint for how the narrative works. While change does occur, it is really only a recycling of past established patterns. Nothing happens, for a long time, the narrator says, in the house and its garden, both of which are terribly old, until "one day at last there did come a change" (2). The change that comes is Griselda, a little girl who has been sent to the house to live with her two great aunts following the death of her mother. Her arrival is a source of consternation for the rooks, who try anxiously to see "what was the matter...A little girl was the matter!" (2). There is a sense that her arrival is perhaps a threat to the property's unchanging existence, but even this is contained by the description of Griselda, who is

A little girl in a grey merino frock...all grey together, even to her eyes, all except her round rosy face and bright brown hair. Her name even was rather grey, for it was Griselda (2).

Her potential for change, signified by her rosy face and bright hair, markers of her youth, is limited by her strong association with the colour grey, with its connotations of old age. Griselda is linked to the past not only by this, but through the memories of the three old ladies, the "aunts" (who were really the much older cousins of her 
grandmother) and the old servant Dorcas. "We are all old here, missie. 'Twas time something young came to the old house again," Dorcas tells Griselda, suggesting that although she is "something young," she is not something new: that "again" points to a repetitive history of which Griselda is an unwitting part (5). Later Aunt Grizzel tells Griselda that she is the third generation of young children entrusted to the aunts' care, following her grandmother and her father. This insistence on permanence and repetition is even echoed in the speech of the two aunts; Aunt Tabitha, the quiet, passive sister, almost never speaks for herself, instead acting as an echo for her more confident and decisive sister. "It was rather a bother to have to always say 'thank you' or 'no, thank you' twice, but Griselda thought it was polite to do so, as Aunt Tabitha always repeated everything that Aunt Grizzel said" (8).

The constant refrain of the aunts is how much she resembles her long-dead grandmother Sybilla: "The aunts looked at each other with a little smile. "“So like her grandmother,' they whispered" (8). This resemblance becomes all the stronger when we learn that Griselda, like her grandmother, has a fascination with the cuckoo clock in the drawing room. Her eventual discovery of the magical cuckoo who lives inside it and their subsequent adventures together, it is strongly suggested, is a secret that Sybilla also knew of. "Just what Sybilla used to say," whispers Aunt Grizzel, when Griselda insists that the cuckoo is alive (12). Later the cuckoo reveals to Griselda, in a dream sequence of moving images, that Sybilla was sent from Germany to live with the great aunts in England, and that the cuckoo clock was made by her grandfather and gifted to her when she came to England. "Griselda" is of course not only a "rather grey" name, it is also a German name, and "Grizzel" is the anglicised form of the name. 
Through their repetition of not only how much she resembles her, but of their hopes that she may turn out "as good as dear Sybilla, if not as beautiful - that we could hardly hope for," Griselda is manipulated by her great aunts into a reincarnation of Sybilla, curtailing the possibility of any difference or of an existence in her own right (78). The change that "came at last" is not so much of a change, it seems, as the beginning of another cycle in a history that is prescribed, and Griselda's status as both a change and an unchangeable "version" anticipates the cyclical structure of the narrative. The cuckoo himself, while for Griselda an agent of change and magic and entertainment, is actually, says Dorcas, the good luck charm that keeps the house safe and happy in an unchanging state. When the cuckoo clock stops after Griselda hurls a book at it, in a rage at her arithmetic sums, this portends for the great aunts not just bad luck, but the cessation of any kind of future. Aunt Grizzel, in great distress, cries: "What can be going to happen? The cuckoo clock has stopped" (23). Without the cuckoo clock, they have no concept of future; or to put it more accurately, the idea of a future, of change, is unthinkable to them because the cuckoo is constant, and represents complete, unchanging continuity. It has been in the house since Sybilla's arrival began the cycle of extreme youth managed by age, and without it, it is suggested, this safe and happy status is threatened.

That it is the cuckoo clock which is the key to the unchanging nature of the house and its inhabitants raises a problem if one of the functions of the return is to be understood as an escape or departure from the restricting norms of the socialised sphere which is inevitably an adult-constructed world. Griselda's fantasies are entirely orchestrated by the cuckoo, who is a very definite "adult" figure, and who 
consistently engages her in catechistical dialogue, albeit not always successfully. Although he takes cues from her daytime activities, for example, her admiration of the carved "Nodding Mandarins" in the drawing room, the cuckoo retains absolute control over what she experiences, acting as a guide and protector, but also as the mediator of her experiences (48). Unlike Diamond and Alice, Griselda is not allowed any role in transporting herself, either during the daytime or at night, to the scene of fantasy. There are no portals, such as the rabbit hole, and unlike Alice, she does not have to figure out the rules herself, as the cuckoo is a thoroughly reliable guide. Unlike Diamond, she has no London to act as a quasi-adult within: even her brief walks outside on the terrace occur only on the occasion of auntly permission.

Griselda is a child who is entirely without agency in the real world, yet the potential for the fantasy world to be a release-valve for the mental pressure of a constrained existence is suppressed too. The cuckoo's control over her extends even as far as her physical movement. She can never understand how she is transported, and neither can the narrator - she is simply "here" one minute and "there" the next, moved by the cuckoo's abilities. When it comes time for her to return, she is never allowed to see the way back, but is always put to sleep in some way, so that she knows "nothing more till she open[s] her eyes the next morning," to wonder "I believe the cuckoo made me fall asleep on purpose to make me fancy it was a dream. Was it a dream?"

The return functions as a curtailing of experience, but to what extent does the fantasy itself act as a controlling agent? Her adventures appear to allow her to play out some potentially dangerous fantasies; dangerous that is, in their "adult" and experiential 
implications. She attends a ball where she dances with the Emperor of China. Like Alice at the Mad Hatter's tea party, Griselda is allowed to participate in a surreal parody of an adult ritual: here her Mandarin suitor and his courtiers are life-size nodding dolls who cannot speak. She also has, like Alice, and like Diamond's friend Nan who is tried out as a helper to the Man in the Moon, experiences of a more profoundly fantastical nature: she is taken to the garden where all the world's butterflies paint all the world's flowers; she visits the lake on the Moon and looks back at the Earth. As Sarah Gilead notes, the return may condone such unsettling experiences by "officially resolving and fixing meanings" once safely back in a "real" setting, but it becomes evident when considering how Griselda's adventures occur that even within the fantasy setting the balance of power lies with the adult figure of the cuckoo (278).

The cuckoo not only hides from Griselda exactly how he transports her, he also selects her adventures and accompanies her, guiding and advising at all stages so that she is neither terrified at the distance between the Earth and the "other side" of the moon, nor does she inadvertently give offence to the King and Queen of the butterflies. So just as the repetitive history of which Griselda becomes a part works to thwart change, ensuring that she is transfixed in her role, so the cuckoo's presence acts to preserve her as a child under the supervision of an adult. No matter how potentially dangerous and profoundly strange and otherwordly her adventures, she undertakes them as a child who is understood through her relationship with the cuckoo who acts both as chaperone and pedagogue, and the series of fantasies is framed as a series of lessons. Indeed, the cuckoo's refrain, “you have a very great deal to learn," and Griselda's initial reluctance to learn the lesson of obedience, 
points to a narrative which is overtly concerned with the importance of preparing a child for subjugation beneath adult rule (49). It is not until Griselda has internalised this lesson, realised that "it's all 'obeying orders' together" which matters and submitted dutifully to the strictures of the aunts that she is rewarded with the official sanctioning of her new daytime playmate, Phil (154). The narrative is resolved with the two children established as friends and the cuckoo, obligingly realising he is not needed any more, bidding Griselda farewell in a "real" dream: "merely a dream, nothing else" (164).

Griselda's very obvious lack of agency bears similarities to the experiences of children in two other "return" fantasies. Alice's adventures and those of the two cousins who find their way into Tapestry Land in another of Mrs Molesworth's children's fantasies, The Tapestry Room, are both conducted under the supervision of adult eyes. While the cousins Hugh and Jeannie appear to negotiate their own way to a greater extent than Griselda, who is instructed by the very adult-sounding cuckoo at every turn where to go and also how to behave, they are still guided by their own "adult" bird, the mysterious and rather frightening raven Dudu. Dudu does not accompany them as the cuckoo does Griselda, but he has complete control over Tapestry Land, and the final say in what happens there and who is allowed entry. Given that Dudu is a French raven, it is tempting to suggest that his name is a sort of "childspeak" play on the French word for "God," "Dieu."7 Certainly Dudu has a godlike omnipresence and omniscience in Tapestry Land. He describes himself to Hugh as merely the "guardian" of the entrance, but also instructs him to whistle three times should he require assistance. When a boat the cousins are attempting to

\footnotetext{
${ }^{7}$ Thanks to my supervisor Harry Ricketts for pointing this out!
} 
navigate up a river runs aground and Hugh whistles, it is not Dudu himself who appears, but a fleet of frogs. Dudu is apparently able to control events in Tapestry Land from some unknown and unseen position.

Alice too encounters adult figures and guides in Wonderland. The advice they give may be meaningless or unhelpful (the Caterpillar's direction to eat one side of the mushroom to grow taller and one to grow shorter without indicating which is which almost results in Alice's annihilation), but they are adult ciphers, and behave in ways which Alice instinctively recognises: "'How the creatures order one about, and make one repeat lessons!' thought Alice. 'I might as well be at school at once'” (Wonderland 74). Griselda experiences a similar attitude from Cuckoo: when she tries to point out a logical inconsistency in his argument, he cuts her off with an adult evasion tactic Alice would have found familiar. “"Nonsense,' said the cuckoo hastily; 'you've a great deal to learn, and one thing is, not to argue"' (49). Dudu, while never a subject of the text's covert mockery in the way that the cuckoo and Alice's guides are, occasionally engages in patronising adult snarkiness. When Hugh tells him he would like to throw a party in the tapestry room castle, “'only,' observed the raven, drily, 'there is one little objection to that. Generally - I may be mistaken of course, my notions are very old-fashioned, I daresay - but generally, people give parties in their own houses, don't they?"' (43).

Dudu, as Jeanne recognises, is rather too frightening a character for mockery. His inscrutable gaze and apparent ability to hear everything said makes him seem a "wicked enchanter": she tells Hugh that it's best to be "most frightfully polite" to him, and even her father addresses him as "Monsieur Dudu" with no trace of irony 
(35). While the narrator of The Cuckoo Clock occasionally delights in pointing out where the cuckoo tries to hide mistakes behind an adult authority, Dudu is above such treatment. When he puts Hugh down, Hugh and the narrator assume a wounded but fearful silence. While the cuckoo and the Wonderland and Looking Glass Land creatures mimic an authoritative but foolish adultness, Dudu represents a sterner adult authority, one that is not necessarily "fair" but maddeningly right. The cuckoo, Dudu and in fact most of the characters populating Wonderland and Looking Glass Land are therefore all parodies or versions of adult behaviour, and their presence as guides of greater or lesser degrees of usefulness points to the impossibility of creating a space that adults are actually outlawed from.

In both The Cuckoo Clock and The Tapestry Room the fantasy setting in which the children find themselves seems to have an intended function, however this might be ultimately thwarted by adult presence, of allowing a form of manageable experience which is not (and should not be, these texts imply) available to the children in their daytime lives. Both fantasies are ones to which the children may return, but only at night, and The Tapestry Room in particular makes it explicitly clear that the two states must be kept separate. When Jeanne and Hugh meet on the morning following their first foray into Tapestry Land, Hugh is upset to discover that although he can remember the night's events clearly, Jeanne appears to have no recollection of what happened. It becomes clear that Jeanne's apparent forgetfulness is, in fact, the "correct" and safe way to deal with these adventures. Marcelline, Jeanne's mysterious nanny who seems well aware of the powers of Dudu and the tapestry room, explains to Hugh that there is "two of everything....and the great thing is to keep each of the twos in its right place" (The Tapestry Room 117). In a subsequent 
fantasy, Hugh is relieved to find that Jeannie does remember, but when he points this out to her she explains, “'You don't understand, Cheri. I'm moonlight Jeanne, now when we were having the dolls' feast I was daylight Jeanne. And you know it's never moonlight in the day-time....I don't exactly forget,' said Jeanne, 'but it spoils things to mix them together'”(128).

It does more than spoil things, as Griselda discovers when she befriends a little boy in the aunts' grounds. They decide to search for the entrance to Fairyland together and become hopelessly lost. When she announces the friendship to Dorcas, the old servant is horrified, for Aunt Grizzel "thinks all boys rude and naughty, I'm afraid, missie" (The Cuckoo Clock 123). What particular type of naughtiness it is that Aunt Grizzel loathes becomes evident when Griselda reveals that Master Phil still has a nurse, and Dorcas considers, “Then he must be quite a little boy, perhaps Miss Grizzel would not object so much in that case" (123). As a very little boy, Phil is harmless, but as someone her own age, he poses a potential sexual threat to Griselda. When Griselda announces this new friendship to the aunts, declares her intent of maintaining it and flies off in a temper when it is forbidden, Aunt Grizzel is swift to attribute blame. “'Already,' she said faintly. 'She was never so violent before. Can one afternoon's companionship with rudeness have already contaminated her?'” (125-6).

It falls to the cuckoo, as usual, to provide an explanation, which he does in the form of the dream sequence. Griselda is shown a scene from a ball in the old house, where a young girl "was dancing with a gentleman whose eyes looked as if they saw no one else, and she herself seemed brimming over with youth and happiness" (72-3). But 
the next scene is of the girl's funeral. The young gentleman paces beside her coffin, white with grief, and when Griselda questions her aunts about this scene, she learns that he dies soon after of a broken heart, and their baby son, her father, was sent to the aunts. Griselda herself has recently lost a mother: this is the reason why she has been sent to live with the aunts.

Dead parents are, in fact, everywhere in these two texts. Sybilla is raised by her grandfather as her parents are dead, and Hugh is sent to live with Jeanne and her family following the death of his parents. Jeanne is the sole child in possession of a full set of parents, but even they have more than a suggestion of mortality about them; her father is much older than her mother and suffers rheumatism. Dudu the raven tells Hugh and Jeanne the story of their ancestors just as the cuckoo shows Griselda hers, along the way remarking that he is somewhere in the region of three or four hundred years old, and again it is a story filled with dead parents and children. The cousins' great-grandmother Jeanne and great-grand aunt befriend a little English girl while they are in their late teens. This girl has lost both her parents. She moves away and the young ladies marry, and do not meet with their English friend Charlotte until many years later, when the Revolution has broken up their family, and Charlotte is able to help Jeanne and her husband escape France. The friends meet up once more, many more years later when all three are old women. Charlotte's and Jeanne's husbands have both died as relatively young men; Charlotte has lost all her children and is herself on her way South to die in a temperate climate in the area where her baby daughter died. 
This sad history, and the history of Griselda's family, makes clear the dangers of marriage and childbearing. It is physically and emotionally damaging, and while this might be read as merely reflecting the realities of an age where death in childbirth and infant mortality was a very real possibility, Aunt Grizzel, at least, believes that these threats are ones that Griselda can be potentially sheltered from through limiting any real experience and interaction with "rude" boys. It is difficult, however, to read Aunt Grizzel's desire to prevent or at least delay Griselda's entry into an adult relationship as that of a radical woman who wishes her great niece free from the unequal power relations of sexual maturity. Griselda's lesson, emphasized again and again, is to learn to obey, and to do her duty, and it is the successful mastery of this lesson which signals that the fantasy may leave off, and the process of forming real friendships with other real children may begin.

Her name refers back to the "Patient Griselda" story, perhaps most well-known for its appearance in Boccaccio's The Decameron, where a young wife uncomplainingly endures heartbreak, humiliation and rejection at the hands of her husband, who merely wishes to test her patience and sense of duty; having done so, he honours her as the ideal woman and all ends happily. It seems that The Cuckoo Clock highlights sexual relationships as a source of damage to women, but rather than propose a radical rejection of the role of wife and mother, Griselda must be sheltered for as long as possible in a state of innocence from what is ultimately inevitable. Her lesson of obedience enforces her position within the text and within the family structure as the newest element of a repetitive narrative. She will, one day, have to endure the deadly pains of childbirth just as her grandmother and her mother have. 
In a similar way, the narrative of The Tapestry Room insists on an absolute separation between the "dream" Jeanne and Hugh, and their "real" counterparts. Just as Griselda may dance with a Chinese emperor in the fantasy realm but must not play with little boys in the "real" world, The Tapestry Room attempts to provide symbolic release and experience in fantasy while prolonging innocence as long as possible in reality. In Tapestry Land, the cousins act as the parents of a strange little family that includes Houpet the chicken, Grignan the turtle, and Nibble the guinea pig, with Dudu as an omnipotent and often unseen protector. Jeanne and Hugh even act out an unwitting parody of the genteel family stroll, walking arm in arm together in stately procession while their "children" walk behind them in obedient pairs. This behaviour is not, however, to be condoned in the "real" world, where the children instead play with dolls and make mud pies. The family history which Dudu tells them functions in the same way as the cuckoo's dream sequence: it shows the disastrous and inevitable consequences of adulthood.

Both texts appear to share on the one hand this belief that fantasy, as a separate world to which the child may journey through some dream-like state, should be a place where unsettling issues may be worked out, future roles tried on and impossible desires acted upon, but also where innocence is presumed. The return to the "real" is a return not only to an adult-regulated site where lessons learned may be demonstrated, but to a place where innocence and safety cannot be taken for granted, where the children must actively perform as children in order to preserve their threatened childishness. The barrier between the two worlds is in this sense absolute, as the safety and inherent innocence of the fantasy world authorizes behaviours 
which are entirely inappropriate in the real, and the child's return fixes this: "By placing the fantasy 'outside' or in the subconscious, such endings can support the stark rationalist oppositions of reality versus fantasy, adult versus child" (Honeyman 126).

But on the other hand, the narratives point to the impossibility of separating the two worlds, and by extension, of separating the fictional child from the adult. Instead of creating sealed off worlds in which Griselda, Jeanne and Hugh can safely play and express themselves, the adult, "real" world to which they belong seeps through into the fantasy, contaminating it with the same power relations the children are faced with in their daytime world. The cuckoo and Monsieur Dudu are for all practical purposes adults. Their relationship to their charges is that of adult to child: they order, teach, scold, and patronise, and they retain absolute control over what the children may and may not do, but they are more than just figures of control. Without the protection and knowledge of the cuckoo, Grizzel would be completely at a loss as to how to behave in the worlds she encounters. Without Dudu, Jeanne and Hugh would remain run aground in their boat, trapped in Tapestry Land. Both sets of children would know nothing of their family history.

This need for an adult chaperone and guide shows that even in the spaces of fantasy, however distinct from the "real" world they appear to be, the child's safety cannot be assured. Far from functioning as a place of anarchic freedom and adventure, the child's experiences, no matter how wild and surreal, must be authorised and mediated by an adult cipher. Fantasy is not, in these texts, a "safe" place for children to be, any more than the "real" world is safe. The presence of the adult signifies that 
innocence cannot be presumed for either space and cannot be presumed for the child, but it also signifies the inability of the child as a fictional construction to exist free from the adult. The return journey device foregrounds the same issue as the fictional child death: the paradox that while the child cannot be successfully imagined or written completely free from the authorial trace of the adult, this close proximity to the fictional child does not allow the adult better knowledge of a theoretical real child, but instead increases the distance between them. 
Conclusion

"I am real!" 
Just as Alice insists upon her independent existence outside of the Red King's dream, so a whole chorus of critics, parents, teachers, social workers, doctors and policy-makers will and do protest that real children do exist and that the child is not merely a textual entity. And of course I cannot disagree: there are children. Karín Lesnik-Oberstein makes a remark in the introduction to Children's Literature which I feel I need to borrow: "Let me be clear: I am in no sense disputing the visible presence of new-born or young human beings" (10). The concern of this thesis has not been to disprove the existence of children or to demonstrate that the only child is a fictional one. It has been to show that although we can know that there are real children, we cannot talk about the real child. I have deliberately left "the child" out of that list of critics who might object to this formulation of children's literature theory, because my intention is to highlight that precise lack of a dissenting child's voice. If children, as they undoubtedly sometimes do, reject how children's literature defines them, decline to collude with the text's authority or refuse to identify with the implied child reader, they cannot make these subversive moves within adultconstructed fictions or criticisms. It is only an adult construction such as Alice who can say "I am real!"

Jacqueline Rose has observed that “If children's fiction builds an image of the child inside the book, it does so in order to secure the child who is outside the book, the one who does not come so easily within its grasp" (2). It is this attempt to "secure" and fix the "real" child which I see as the move to be aware of, which reveals the inherent inequality of power between adult and child. If all children's literary criticism is fundamentally concerned with "How to find the good book... whichever way it is dressed up," as Lesnik-Oberstein maintains, we must ask "good for which 
child?" (Children's Literature 5). This is a question which should be unanswerable. It would be a naïve critic who described the exact sort of real reader for whom Catch-22 was ideal, and yet, Lesnik-Oberstein observes,

Because it is assumed that children can be understood, or known, the problems that adult literary criticism engages with seem simplified. To put it crudely, children's literature criticism uses the idea that adults know how children think and feel to 'solve' the problems that adult literary criticism struggles with precisely because it is not sure it is easy for people to know or understand how another person thinks or feels (Children's Literature 6).

As Perry Nodelman and Rose argue, the concept of colonialism is an apt metaphor for children's literature, since “children's fiction has a set of long-established links with the colonialism which identified the new world with the infantile state of man" (Rose 50). Children's literature, says Nodelman, "might be best characterised as that literature which works to colonise children by persuading them that they are as innocent and in need of adult control as adults would like them to believe" (The Hidden Adult 163). As well as these obvious parallels of power, protection and control, colonialism shares with children's literature the assumption that its subjects are unable to speak for themselves, and must be spoken about by practitioners who are by definition outside the field. The Oriental can only be spoken by the Orientalist; "the children that children's literature purports to address must be the children of shared adult wisdom" (Nodelman The Hidden Adult 165). 
The fundamental difference, of course, is that the peoples who were once pinned beneath the colonial gaze have since turned that gaze back. Colonialism has become a subject to be deconstructed by those who were its subjects. It is arguable that this can never be possible for the subjects of children's literature; in order to become a practitioner and critic of the literature which is both for and about them, children must grow up, and write, as adults, for a memory of themselves. Whether writing as authors or critics, "Childhood, and a childlike point of view are...constructs of adult minds that adults work to impose on children, in part by means of children's literature" (Nodelman The Hidden Adult 193). The only possible child about which we can know anything is one articulated by an adult. The "real" children, the ones whose existence we cannot deny, will always remain beyond the text, unreachable and unspeakable; in this sense they are Derrida's absence, the "nothing" which is outside the text.

Wholly imaginary, these children outside the text may be real, but for the purposes of children's literature and criticism they are only theoretical; an encounter with adult language would irreparably taint them. Deferring to Derrida again (he is writing on empiricism, but invokes his famous conception of the trace): "It is the dream of a purely heterological thought at its source. A pure thought of pure difference... We say the dream because it must vanish at daybreak, as soon as language awakens (Writing and Difference 151). While the "dream" or thought of a pure child is possible, in practice it contains the trace of its other, the adult. Nodelman, who has engaged Derrida and children's literature before, explains that "the childlike can be constructed and explained only in relation to that which it is 
not," or, we understand "child" because we can posit "adult" (The Hidden Adult 206).

But Derrida is doing something more serious than identifying what appears to be a human habit of binary thinking. Language, Derrida says, makes pure difference impossible. Consequently, the child contains within it the trace of the adult; when an attempt is made to write the child, the adult cannot be got rid of. In the first chapter of this thesis, I briefly sketched an outline of the implied child readers, which there is a very strong sense of, in all my selected Golden Age texts. What all the texts have in common is the way in which the narrative creates this implied child reader: through the construction of an adult narrative voice which hail the child reader directly. A variation on this voice, which is friendly, comfortable, even conspiratorial, is present in all eight texts, and even while it invites collusion, it speaks as an adult to the child, in the voice of authority. The narrators address the readers as "my child," "my little man," "children," "my good little Englishman" and suggest or instruct constantly: "shall we?" "you wouldn't have," "you shouldn't," “would you like to?" and so on.

This adult, "auntly" voice is a familiar part of the Victorian children's narrative, and yet it has faded out of children's literature. It lingers in Edwardian literature in the works of Nesbit and Kipling, but is almost entirely absent in later twentieth century children's books. What this points to is more than a reflection of changing tastes and a tendency to view the Victorian auntly narrator as a condescending, rather twee device. The term “Golden Age of children's literature” marks a sustained period where, for the first time, works of a substantial length were produced for and seized 
by a child audience, and which appeared to rely more on imagination and fantasy than overtly educative tendencies. ${ }^{8}$ It also marks the rise of the children's literature smash hit, the narrative (Alice in Wonderland is the most obvious example) which was read by thousands and enjoyed a highly visible public success.

Written in this first flush of the popularity of the genre, I read in these narratives a profound self-consciousness and self-interrogation of the practise of writing for children. The voice of the adult narrator - didactic, authorial and jarring, breaking in on the plot to address the reader - serves as a reminder. The narrative is being written, and it is being written by an adult, and the adult narrative voice constantly draws attention to this fact. Rather than encourage the readers to lose themselves in the book, these narrators are on guard against, and seek to prevent, the utter dissolution of the discursive artifice. When the narrator of North Wind comments that it will be hard for him to tell exactly what happened at the North Wind's back because "I do not know enough about it," he calls on the implied reader to notice the artificial nature of narrative, to consider that it is created by an adult authority (91).

These texts are united by the shared self-conscious insertion of the adult narrator, and by a related theme, which the adult narrator can be seen as working to expose. The narratives all enact a debate about the possibility of writing a child, of whether this is a goal which can be achieved or even desired. All the texts discussed here, from the first Romantic construction of childhood through to Mrs Molesworth's two

\footnotetext{
${ }^{8}$ It can be and is, debated whether The Water Babies, George MacDonald's fantasies and the Alice texts were actually intended exclusively for child readers. Leaving aside irresolvable questions about authorial intention, I locate the intended audience in the implied child reader, having doubts as to whether any Victorian gentleman would read "my dear little man" as an address to himself. See Lila Marz Harper's chapter “Children's Literature, Science and Faith: The Water Babies" in Children's Literature: New Approaches for a further discussion of this issue.
} 
return fantasies, carry within them an awareness of Rousseau's conception of the child as original, as pre-fallen, as a point of purity and innocence which the adult can somehow return to and access. This child is not, for any of the texts, something that may be taken for granted, but rather a construction which must be questioned. As Wordsworth and Hartley Coleridge demonstrate through their attempts to address this child, even if such a child does exist, it does so in a space which the adult can never approach. The Romantic child, even for Wordsworth, the man who is so often cited as its author, remains beyond the adult and beyond communication.

To render the child communicable, to talk to and about it, the adult must "stain the waters clear" as Blake shows. The children of his Songs offer a different interpretation of "innocence": it means to lack knowledge and awareness. His innocent children are simply unaware that they are experienced. To live, in a world that is created by and for adults, is to be experienced, even for the child. It is this proposition which I read the Golden Age texts as responding to and attempting to work out. To varying degrees, all attempt to create worlds and spaces and even languages from which the adult is banished, and where that theoretical innocent child might exist unimpeded by adult language. The Alice and the Princess texts attempt this at the level of language, while The Water Babies and At The Back of the North Wind try to free the child in death, and The Cuckoo Clock and The Tapestry Room use the parallel fantasy world. Not all of the texts can be said to be "trying as hard" as others; The Water Babies' didactic narrator and The Cuckoo Clock's overt lesson of obedience create narratives which ultimately enforce adult control, while George MacDonald and Lewis Carroll's texts make sustained attempts to imagine a child that is "really" free. 
I have referred to these efforts as "circular" or as "moving towards" this idea of the free and innocent child, and these terms are appropriate for what I see as a continual approach or reach for "the child," this concept which is also an impossibility, an absence sitting at the heart of each text. While each comes very near this absence, they cannot actually reach it, cannot grasp "the child" and pin it down. Its very status as absence, as a thing which is not, precludes it from being reached. It exists as an ideal perhaps, but as my reading of the texts shows, the moment "proper" language touches this ideal, it ceases to be the child and becomes the adult. The problem of writing the child is that it is not real; for all Alice's protestations to the contrary, she still "goes out" when the creative authority of the narrative "leaves off" his story.

This thesis has unconsciously mimicked the circular moves which the texts rehearse, gesturing towards a problem, an absence at the heart of children's literature criticism without actually touching it. I am all too aware that in making the claim that we have no way in which to speak about the child without invoking our own adultness and tainting the child, I have proposed no solution. I am similarly aware that in exposing how criticism supposes knowledge of child readers and forces those readers into the standardised category of "child," I have had to do the same for the term "adult," proposing a unitary concept of adulthood which is single-minded in the ways it sees and speaks of children. The relationship of power between the adult and the child is culturally and naturally inscribed, and it is in some sense a necessary one. This relationship will not deconstruct itself as other power relations have: children will not have their post-colonialism, feminism, queer theory or Marxism. It is the fact that as adults we not only have these fragmented and endless ways of writing 
ourselves, but the power and the cultural capital to do so that makes me feel less uncomfortable with my very crude homogenisation of adulthood.

I realise now that I have imitated not only the circular structure of the texts, but also their self-conscious voices: I am constantly present as narrator, announcing my intentions just as the narrators of the texts do. In both cases this is the trace of uncertainty. Children's literature is now an established and respected genre, and its twentieth and twenty-first century practitioners show none of this sense of unease with writing the child. Alan Garner and Susan Cooper, Diana Wynne Jones and more recently, Phillip Pullman, have all produced fantasy for children which is complex, challenging and above all supremely confident in its ability to speak not only of children, but from a child's point of view. Their fractured, powerful narratives, rampaging through myth, canon, point of view, allegory, postmodernism and history, do not rely on the voice of a narrator to intercede between the child in the book and the child which is imagined to be outside of it, as the Golden Age texts do.

I highlight this confidence because as critics and as adults we should be aware when claims to know the child are made, and proceed with caution. Doubtless others will take issue with my formulations and they will argue against them; they will have both the right and the ability to do what the child does not. What this thesis has demonstrated is that Victorian children's fantasy texts were alert to the problems of writing the child and actively engaged in a debate as to whether the fictional child could ever, or should ever, approach the real child. As critics of children's literature, we need to bring to our readings the same awareness and sensitivity. 
Works Cited 
Alighieri, Dante. The Divine Comedy. Trans. Allen Mandelbaum. Intr. Eugenio Montale. Everyman Millennium Library. London: Bantam-Doubleday, 1995. Print.

Auerbach, Nina. "Alice and Wonderland: A Curious Child." The Victorian Child. Spec. issue of Victorian Studies. 17.1 (1973) 31-47. JSTOR. 15 April 2009. <http://www.jstor.org/stable/3826513>. Print.

Austin, Linda M. "Children of Childhood: Nostalgia and the Romantic Legacy." Studies in Romanticism. 42.1 (2003): 75-97. ProQuest. 23April 2008. <http://www.proquest.com.helicon.vuw.ac.nz/> Print.

Barthes, Roland. "Death of the Author." Image Music Text. New York: Hill \& Wang 1977. Print.

Blake, William. Selected Poetry. Ed. \& intr. W. H. Stevenson. London: Penguin, 1988. Print.

Bronte, Charlotte. Jane Eyre. (1847) Ed. Richard Nemesvari. Broadview Literary Texts. Peterborough, Ont.; Orchard Park, NY: Broadview Press, 2004. Print.

Burman, Erica. Deconstructing Developmental Psychology. London: Routledge, 1994. Print.

Carroll, Lewis. Alice's Adventures in Wonderland and Through the Looking Glass. (1865; 1871) London: Dean \& Son, 1896. Print.

Cocks, Neil. "Writing, Death and Absence in Tim by H.O. Sturgis." Nineteenth-Century Contexts. 26.1 (2004) 47-60. Informaworld. 4 May2009. <http://www.informaworld.com/smpp/search>.Print.

Coleridge, Hartley. New Poems: Including a Selection from his Published Poetry. Ed. Earl Leslie Griggs. London: Oxford UP, 1942. Print. Coleridge, Samuel Taylor. Coleridge's poetry and prose: authoritative texts, 
criticism. Eds. Nicholas Halmi, Paul Magnuson, Raimonda Modiano. New York: W.W. Norton, 2004. Print.

Coveny, Peter. The Image of Childhood: The Individual and Society: a Study of the Theme in English Literature. Intr. F. R. Leavis. Harmondsworth: Penguin, 1967. Print.

Derrida, Jacques. Of Grammatology. (1967) Trans. Gayatri Chakravorty Spivak. Baltimore: Johns Hopkins UP, 1997. Print.

---. Writing and Difference. (1967) Trans. \& intr. Alan Bass. London: Routledge, 1993. Print.

Eliot, George. Middlemarch. (1871-2) Ed. Rosemary Ashton. Harmondsworth: Penguin Classics, 1994. Print.

Gilead, Sarah. "Magic Abjured: Closure in Children's Fantasy Fiction.” PLMA 106.2 (1991): 277-293. JSTOR. 11 June 2008. <http://www.jstor.org>. Print. Hancher, Michael. "Humpty Dumpty and Verbal Meaning." The Journal of Aestheticsand Art Criticism 40.1 (1981): 49-58. JSTOR. 19 March 2009. <http://www.jstor.org/stable/430352>. Print.

Herdman, John. The double in nineteenth century fiction. Basingstoke: Macmillan, 1990. Print.

Honeyman, Susan E. “Childhood bound: In garden, maps, and pictures.” Mosaic. 34.2(2001): 117-133. ProQuest. 2 April 2008. <http://proquest.umi.com.helicon.vuw.ac.nz>. Print.

Inglis, Fred. The promise of happiness: Value and meaning in children's fiction. Cambridge: Cambridge UP, 1981. Print.

Jackson, Mary V. Engines of Instruction, Mischief, and Magic: Children's Literaturefrom Its Beginnings to 1839. Lincoln: U of Nebraska P, 1989. 
Print.

James, Allison, Chris Jenks \& Alan Prout. Theorizing Childhood. Cambridge: Polity; Blackwell, 1998. Print.

Jenks, Chris. Childhood. London; New York: Routledge, 1996. Print.

Keanie, Andrew. "Hartley Coleridge: Son of the Mariner, King of Ejuxria."

Coleridge Bulletin. NS 28 Winter (2006): 54-62. Print.

Kincaid, James. Child-loving: the erotic child and Victorian culture. New York: Routledge, 1992. Print.

Kingsley, Charles. The Water Babies. (1863). London; Glasgow: Blackie \& Son, n.d. Print.

Knoepflmacher, U. C. "Little Girls without Their Curls: Female Aggression in Victorian Children's Literature.” Children's Literature. 11 (1983):

14-31. Project Muse. 28 January 2009. <http://muse.jhu.edu/search>. Print.

Lesnik-Oberstein, Karín. "Childhood and Textuality." Children in Culture:

Approaches to Childhood. Ed. Karín Lesnik-Oberstein. Basingstoke; New York: Palgrave Macmillan, 1998. Print.

---. Children's Literature: Criticism and the Fictional Child.

Oxford: Oxford UP, 1994. Print.

MacDonald, George. At the Back of the North Wind; The Princess and the

Goblin; The Princess and Curdie: Complete and Unabridged. (1870; 1871;

1882) London: Octopus, 1979. Print.

---. Lilith. (1895) Intr. Lin Carter. London: Ballantine, 1971. Print.

May, Jill P. Children's Literature and Critical Theory: Reading and Writing for

Understanding. New York; Oxford: Oxford UP, 1995. Print.

May, Leila S. "Wittgenstein's Reflection in Lewis Carroll's Looking-Glass." 
Philosophy and Literature 31.1 (2007): 79-94. Project Muse. 20 March 2009. $<$ http://muse.jhu.edu/search>. Print.

McGillis, Roderkick. The Nimble Reader: Literary Theory and Children's Literature.

New York: Twayne Publishers, 1996. Print.

--- ed. For the Childlike: George MacDonald's Fantasies For Children.

Metuchen, N.J.; London: The Children's Literature Association \& Scarecrow Press, 1992. Print.

Molesworth, Mrs. The Cuckoo Clock. (1877) Intr. Emma Chichester Clark. London:

Jane Nissen Books, 2002. Print.

---. The Tapestry Room: a child's romance. (1879) London: Tom Stacey, 1972.

Print.

Myers, Mitzi. "Romancing the Moral Tale: Maria Edgeworth and the

Problematics of Pedagogy." Romanticism and Children's Literature in

Nineteenth-Century England. Ed. James Holt McGavran, Jr. Athens: U of Georgia P, 1991. Print.

Nikolajeva, Maria, ed. Aspects and Issues in the History of Children's Literature.

Contributions to the Study of World Literature 60. Westport, C.T.;

London: Greenwood Press, 1995. Print.

Nodelman, Perry. The Hidden Adult: Defining Children's Literature. Baltimore:

The Johns Hopkins UP, 2008. Print.

---. "The Hidden Meaning and the Inner Tale: Deconstruction and the

Interpretation of Fairy Tales." Children's Literature Association Quarterly.

15.3 (1990): 143-148. Project Muse. 17 April 2009.

$<$ http://muse.jhu.edu/search>. Print.

Pfefferkorn, Kristin. Novalis: a romantic's theory of language and poetry. New 
Haven: Yale UP, 1988. Print.

Plotz, Judith. Romanticism and the Vocation of Childhood. New York;

Basingstoke: Palgrave, 2001. Print.

Reynolds, Kimberley \& Paul Yates. "Too Soon: Representations of Childhood Death in Literature for Children." Children in Culture: Approaches to

Childhood. Ed. Karin Lesnik-Oberstein. Basingstoke; New York: Palgrave Macmillan, 1998. Print.

Richardson, Alan. “Wordsworth, Fairy Tales, and the Politics of Children's

Reading.” Romanticism and Children's Literature in Nineteenth-Century

England. Ed. James Holt McGavran, Jr. Athens: U of Georgia P, 1991. Print.

Rose, Jacqueline. The Case of Peter Pan or The Impossibility of Children's Fiction.

Philadelphia: U of Pennsylvania P, 1984. Print.

Rousseau, Jean-Jacques. Emile, or, Education. (1762) Trans. Barbara Foxley.

London: Dent; New York: Dutton, 1911. Print.

Sandner, David. The Fantastic Sublime: Romanticism and Transcendence in

Nineteenth-Century Children's Fantasy Literature. Westport, C.T.; London:

Greenwood Press, 1996. Print.

Shires, Linda M. "Fantasy, Nonsense, Parody and the Status of the Real: The

Example of Carroll.” Comic Verse. Ed. Ina Rae Hark. Spec. issue of

Victorian Poetry 26.3 (1988): 367-283. JSTOR. 2 April 2009.

<http://www.jstor.org/stable/40001965>. Print.

Sircar, Sanjay. "The Victorian Auntly Narrative Voice and Mrs. Molesworth's

Cuckoo Clock" Children's Literature. 17 (1989): 1-24. Project Muse.

1 June 2009. <http://muse.jhu.edu/search>. Print.

Sky, Jeanette. "Myths of Innocence and Imagination: The Case of the Fairy Tale." 
Literature \& Theology. 16.4 (2002): 363-376. ProQuest. 15 May 2008.

<http://www.proquest.com.helicon.vuw.ac.nz>. Print.

Straley, Jessica. "Of Beasts and Boys: Kingsley, Spencer, and the Theory of

Recapitulation.” Victorian Studies. Summer (2007): 583-609. Project Muse.

19 January 2009. < http://muse.jhu.edu/search>. Print.

Stevenson, Robert Louis. The Strange Case of Dr. Jekyll and Mr. Hyde. (1886) Ed.

Richard Dury. Edinburgh: Edinburgh UP, 2004. Print.

Summerfield, Geoffrey. Fantasy and reason: children's literature in the eighteenth century. London: Methuen, 1984. Print.

Thacker, Deborah, \& Jean Webb. Introducing children's literature from Romanticism to Postmodernism. London; New York: Routledge, 2002. Print.

Thornton, Sarah. "The Vanity of Childhood: Constructing, Deconstructing, and Destroying the Child in the Novel of the 1840s." Children in Culture: Approaches to Childhood. Ed. Karin Lesnik-Oberstein. Basingstoke; New York: Palgrave Macmillan, 1998. Print.

Tucker, Nicholas, ed. Suitable for Children? Controversies in Children's Literature. London: Sussex UP, 1976. Print.

Wordsworth, William. Lyrical Ballads, and other poems, 1797-1800. Ed \& intr. James Butler \& Karen Green. Ithaca: Cornell UP, 1992.

---. The Major Works. Ed \& intr. Stephen Gill. Oxford;

New York: Oxford-Classics, 2000. Print. 
